\title{
The Plague, a Metal Monster, and the Wonder of Wanda: In Pursuit of the Performance Style
}

\author{
David Kjar (Boston University, Boston, EUA) \\ kjard@bu.edu
}

\begin{abstract}
The claim of having achieved "authenticity" in performance has today almost disappeared without a trace. However, Richard Taruskin's efforts to disprove the premise through a series of articles in the 1980s still beg important questions, such as exactly what are the origins of the early music movement's performance style and which performers had a role in its transmission? Taruskin contends that Stravinsky transmitted the "geometrical," or modernist, Bach to the musical world, and that Stravinsky might have learned it from Wanda Landowska. Taruskin's accolade exposes more than a bit of irony within the early-music revival, since Landowska is seldom, if ever, acknowledged as a significant contributor to the development of the early-music "style" of performance, even though Landowska's recordings reveal a performer with a modern style, one that foreshadows 1980s early-music performances. Due primarily to the sound of her non-historic harpsichord, Landowska's influence, however, has been diminished, and her significant role was negated in the post-"authenticity" early music movement. This paper traces Landowska's central influence through an investigation of her Varsovian musical education, Parisian residency, and recordings. It recognizes and advocates for the contributions made by Landowska before the advent of the "authenticity" era.
\end{abstract}

Keywords: Historical Performance; Early Music; Authenticity; Performance Practice; Landowska; Kleczyński.

\section{A praga, o monstro de metal e a maravilha de Wanda: em busca do estilo de performance.}

Resumo: A defesa por uma performance "autêntica" quase desapareceu sem deixar traços. No entanto, os esforços de Richard Taruskin para contestar o conceito nos anos 80 ainda provoca muitas questões importantes, como o que são as raizes do estilo de performance de música antiga e quais intérpretes tiveram um papel em sua transmissão. Taruskin argumenta que Stravinsky transmitiu o Bach "geométrico", ou modernista ao mundo musical e que Stravinsky poderia tê-lo aprendido de Wanda Landowska. 0 elogio de Taruskin expõe mais do que uma certa de ironia dentro da restauração da música antiga, uma vez que Landowska é raramente, ou mesmo nunca, reconhecida como uma colaboradora para o desenvolvimento do estilo de performance da música antiga. Este ensaio revela a influência de Landowska através de uma investigação de sua educação musical em Varsóvia, sua estadia em Paris e suas gravações. Estas últimas revelam uma intérprete com um estilo moderno, que antecipa as performances de música antiga dos anos 80. Graças ao som de seu cravo não-histórico, a influência de Landowska tem sido minimizada e seu papel significativo foi negado no movimento de música antiga "pós-autêntico". Este artigo reavalia as contribuições feitas por Landowska antes do advento da era da "autenticidade".

Palavras-chave: performance histórica; música antiga; autenticidade; prática de performance; Landowska; Kleczyński.

\section{1 - Introduction}

Richard Taruskin's campaign berating early music's dependency on "authenticity" as a defense for its performance style, now seems irrelevant or even alien (TARUSKIN, 1988).' For today, the claim of "authentic" performance has almost disappeared without a trace. However, the effort to disprove historicism still begs important questions, such as what exactly are the roots of the early music movement's performance style and which performers had a role in its transmission?
Taruskin reminds us that there is no way of knowing what music sounded like in the eighteenth century and, therefore, the early music movement's claim of "authenticity" cannot be substantiated. He asserts that the performance style of the early music movement is a geometrical one and has its origins, rather, with Igor Stravinsky and the early twentieth-century modernists. Geometricism, with its stiff angularity and emphasis on objectivity, is in opposition to the softer vitalist style, a style exhibited by 
nineteenth-century "Romantics" in their early twentiethcentury recordings (TARUSKIN, 1988). ${ }^{2}$ Taruskin hypothesizes that Stravinsky learned his geometricism from Wanda Landowska in 1907 (TARUSKIN, 1988, p.167). ${ }^{3}$ His accolade exposes more than a bit of irony within the early music revival, since Landowska is seldom, if ever, acknowledged as a significant contributor to the development of the early music movement's style of performance. ${ }^{4}$

Landowska was a flamboyant performer of the highest regard, and her recordings exhibit a distinctive and modern style, one that foreshadows period-instrument performances of the 1980s. Due primarily to the sound of her Pleyel harpsichord combined with the theatricality of her performance style, Landowska's influence, however, has been diminished and her significant role was negated in the post-"authenticity" early music movement. Using Taruskin's theory as a starting point, this paper reevaluates Landowska's contribution to the early music movement's style of performance within the philosophical and musical framework of the "authenticity" movement.

\section{2 - The Plague}

The history of the early music movement is a capricious one; its chronicle leaves off or deemphasizes those members who do not fall within present criteria. Despite the movement's tendency to play up its kaleidoscope-like characters, Landowska, an exotic woman with strong musical ideas, plays the one-dimensional role of harpsichord advocate. Her script requires very few lines beyond the resurrection of and advocacy for her instrument, and most would agree that Landowska is not on the early-music marquee with Harnoncourt, Leonhardt, and Brüggen. ${ }^{5}$ These three headliners brought the early music movement's performance style to a mainstream audience and secured it with widely circulated recordings. They spearheaded in the 1960s and 1970s what Stephen MEYER (2009, p.248) recently called the "modern" early music movement. ${ }^{6}$ But what influence does Landowska and other performers from the "pre-modern" early music movement have upon our performance style? And why is Landowska's generation not considered modern?

There is a disconnect between the accomplishments of Harnoncourt, Leonhardt, and Brüggen, and those of the previous generation. For standing defiantly between the two generations is the Achilles' heel of the early music movement - "authenticity." It is difficult to determine when the "authenticity" movement began, but by the mid-1960s it had gained momentum. In 1968, Harnoncourt signaled the movement's authentistic resolve:

Today we only want to accept the composition itself as a source, and present it as our own responsibility. The attempt must thus again be made today, with Bach's masterpieces in particular, to hear and perform them as if they had never been interpreted before, as though they had never been formed nor distorted (HARNONCOURT, 1968).
In the 1980s, many of the prominent leaders in the early music movement signed on to the "authenticity" campaign and enthusiastically waved its flag in support of their own performance style. "Authenticity" was entrepreneur-friendly and records heralded claims such as "Pachelbel's Canon: The Famous Canon as Pachelbel Heard It" (HOGWOOD, quoted by KENYON, 1988, p.6).

Due to Taruskin's widely published criticism of "authenticity" in the mid-1980s, the term became permanently accessorized with quotation marks, and today the early music movement rarely speaks its name. But like a scar left from The Plague, the residual mark of "authenticity" still remains. It is embedded in the movement's performance ideals and defines what is or is not historical performance. One residual is that an early-music ensemble must perform on period instruments. This ideal is apparent in Stanley Sadie's criticism of musicians "aping" the early-music style of performance on modern instruments:

There is little point in aping the sound, or the balance, of the groups
we know to have been used by composers of the Baroque if we
employ instruments and voices altogether different from the ones
from which they conceived their music (SADIE, 1998 c1990, p.440).

The use of "authentic" instruments in the place of the modern equivalent is a mid-twentieth-century development that was fully embraced by the early music movement in the 1970s. However, before the discovery and proliferation of period replicas, the movement held aloft a different ideal - an ideal defined by repertoire rather than medium. In the nineteenth century and the beginning of the twentieth, an ensemble committed to the performance of early music most often performed on instruments from their period. The leaders of these ensembles unearthed and realized old music and were reported, with their "modern" forces, to have rendered compelling performances.

Alexandre-Etienne Choron (1771-1834) was one such early-music leader. He was an advocate for the golden age of French music, which for him was the late-Medieval and Renaissance. Choron's ensemble Ecole royale et spéciale de chant, at its peak in the late 1820s and early 1830s, presented nearly fifteen concerts a year. These concerts programmed sacred vocal works from the sixteenth, seventeenth, and early eighteenth centuries including Monteverdi, Josquin, and Handel. ${ }^{7}$ Some of the performances engaged a choir of over 600 voices, accompanied by an organ or piano paired with a violoncello and double bass (SIMMS, 1971, p.148-150).

At the end of the nineteenth century, Charles Bordes (1863-1909) took up where Choron left off. Bordes, a pianist and composer who studied with César Franck, was appointed choirmaster of Paris's Saint-Gervais, where with the Chanteurs de Saint-Gervais he gave numerous performances of early repertoire ranging from Palestrina to Bach to Schubert. ${ }^{8}$ As with Choron, Bordes did not 
require period instruments for the performance of early repertoire. When presented with a choice, he preferred the modern one. In his 1903 letter to Landowska, Bordes discouraged the use of the harpsichord for works written with the harpsichord in mind:

\footnotetext{
I want to put you to a big task, one which may become for you a splendid specialty. Play all the works of the harpsichordist, but not on the harpsichord; enough of this "cage for flies" which reduces superb and often large-scale works to the size of its tiny, spindly legs (RESTOUT, 1965, p.10)
}

Despite the employment of modern instruments, nineteenth-century operatic singing techniques, and Berliozlike performance forces, these leaders were considered early-music experts. For a nineteenth-century and early twentieth-century audience, conventions such as these did not deter the enjoyment of an early-music performance or make it "modern" in a derogative way. In all probability, these conventions made the early repertoire more palatable. $^{9}$

There were also early-music ensembles in the late-nineteenth century that performed on a mix of period and modern instruments, such as the harpsichordist Louis Diémier's Société des instruments anciens with Louis van Waefelghem (viola d'more), Laurent Grillet (hurdygurdy), Jules Delsart (viola da gamba), Paul Taffanel (flute), Georges Gillet (oboe d'amore), Guillaume Remy and Armand Parent (violins). Société presented exhibition concerts at the 1889 World's Fair that set the stage for performances at the Salon Pleyel in Paris (1895) and a tour of London (1897) and St. Petersburg (1907). Their repertoire included works by Rameau, Bach, Couperin, Lully, Handel, and Marais. ${ }^{10}$ For the most part, the Société used period instruments, but the idea of a "Baroque" set-up on the violin or even an old flute was unheard of, for period replicas of these instruments were outside the realm of possibility.

Membership in the nineteenth-century and early twentieth-century early music movement did not require historical instruments; the emphasis, rather, was on the repertoire. The popularity of "authenticity" in the 1960s, with its focus on period replicas, redrew the boundaries of the movement and left a number of committed earlymusic performers outside its borders. Taruskin's defrocking of "authenticity" exposed unsightly holes in the undergarments of the movement's defense for its performance style and sobered the movement's authentistic resolve..1 Ever since, members of the early music movement have struggled to redefine "historical" in relation to their historically informed performance. Recent efforts have been fruitful, and it is safe to say that the plague of "authenticity" has finally receded, but unfortunately it has taken Landowska with it. One particular recording by Landowska in the late 1930s exhibits traits of the early music movement's performance style and gives ample cause to bring her back into the fold.

\section{3 - The Sound of "Historically Informed"}

My introduction to Landowska came in the form of her 1937 recording of Mozart's "Coronation" Concerto K537. ${ }^{22}$ Despite Landowska's unauthentic reputation, her piano playing on this record sounds "historically informed." But how is the sound of "historically informed" defined? A list of descriptors, many of which are part of the early music movement's jargon, come to mind, such as transparent texture, light tone, articulated style, cellular phrasing, beat hierarchy, speech-like or rhetorical rendering, and ornamental or non-continuous vibrato..$^{13}$ The exclusive application, however, of these descriptors to the early-music style of performance is problematic, for all compelling performances - modern or Baroque - contain to some degree these elements. ${ }^{14}$

Landowska had access to Urtext-like editions and period instruments. On a concert tour before World War I, she played a Mozart piano housed in Salzburg's MozartWohnhaus (ZALTSBERG, 2002, p.18). She also had a vast library - approximately 10,000 volumes - that included the Bach-Gesellschaft and "12 volumes of music by Mozart." (DE VRIES, 1996, p.225) ${ }^{15}$ The latter collection could have been issues of the late nineteenth-century Mozart Gesamtausgabe. These materials surely informed Landowska's performance, but as we shall see, she might have crafted her "historically informed" approach in Warsaw with Jean Kleczyński, well before she gained access to scholarly sources and period replicas.

Luckily, Neal Zaslaw provides a tangible definition for "historically informed," conveniently addressed towards the "Coronation" Concerto. In his liner notes to Malcolm Bilson and John Elliot Gardner's 1988 recording, Zaslaw re-notates the opening motive of the first movement. His redressing of the motive provides "the supposedly 'missing' marks of articulation and expression, which are lacking (or only haphazardly applied) in all too many modern performances of the music of Mozart and his contemporaries, but restored by Bilson and Gardiner in the present performances." (ZASLAW, 1988) Here, Zaslaw's definition of historically informed is obvious - play shorter. In strict fashion, his realization halves all notes marked with a dagger - as well as the last note in a series of tones under a slur. He also indicates various degrees of emphasis with small dashes stacked on top of each other; three dashes are reserved for the strongest beats. Zaslaw's example, peppered with thirty-second notes and rests, has visually "restored" Mozart. His restoration - probably to Taruskin's satisfaction - also resembles a score of Stravinsky's L'Histoire du soldat.

But what does historically informed sound like in Landowska's recording? I must admit that I came to this recording with some trepidation, and the crackling and hissing of the needle's first trip around the LP did not alleviate my uneasiness with early twentieth-century recordings of this repertoire. To my surprise, I imme- 
diately recognized, in the opening measures of the orchestra's exposition, signs of "historically informed" playing as defined by Zaslaw. The bass group and violas execute the repeated quarter notes as eighth notes. The first violins play the initial motive with a narrow, nonregular vibrato and phrase the stroked eighth notes as if they were reading from Zaslaw's edition. In the second key area, the strings render the eighth notes, paired by slurs, in typical early-music fashion - long short, long short. ${ }^{16}$ Even the beat hierarchy is adhered to: beat one receives emphasis, and the quarter notes on the second and fourth beats at the end of the lyrical phrases are released gracefully. ${ }^{17}$ The tempo is steady, and the rhythm remains poised - with just a tinge of that Flemish style that hesitates ever so slightly before the resolution of certain structural cadences. ${ }^{18}$ Granted, the orchestra exposition is not terribly compelling, but my point is that this interpretation is not "Romantic." This late-1930s recording fits into the early-music mode of performance as clearly illustrated by Zaslaw in $1988 .^{19}$

Landowska's entrance takes Zaslaw's concept of short a few steps further, for in the piano's opening statement - an ornamented version of the orchestra exposition Landowska plays both short and long. Even though the intricate detail of each rhythmic cell is clearly etched, the long-term orientation dictated by the harmonic progression is still felt; her musical line speaks and sings at the same time.

But perhaps it is at the end of the piano's first statement that Landowska comes closest to our notion of "historically informed," where the orchestra moves aside and the piano's eighth notes ascend and descend in diatonic steps, eventually giving way to a flourish of triplets hinged to the tonic triad. ${ }^{20}$ In these four measures, Landowska is at her best. She applies the stepwise eighth notes with a thick but firm brush - broadening them ever so slightly. The triplets are flicked off in one stroke, and the final cadence naturally dissipates. Over all of this detail, an unrelenting diminuendo blends the frenzy of changing note values and alternating stepwise and triadic motion into a coherent line. Landowska's rendering is neither overly meticulous nor obsessively goal-oriented. Instead, her performance is both poised and driven. Landowska's interpretation eased my trepidation. My early-music aesthetic was placated. And I wondered why I had not considered Landowska a significant contributor to the early music movement's performance style.

\section{4 - Haydn and the Metal Monster}

My mood, however, quickly changed when I flipped the record over to the B-side. There, waiting for me, was Haydn's Concerto in D, Op. 21 - recorded on the harpsichord. ${ }^{21}$ The sound of Landowska's Pleyel is almost indescribable: a hybrid of a harpsichord, pianoforte, hammered dulcimer, and mini-Casio keyboard. In addition to the cacophonous tone, it sounds as if the microphone is secured to the soundboard - positioning my ear directly in her instrument. ${ }^{22}$ Her harpsichord, what Joel Cohen dubbed "the metal monster," made my "authenticity" scar burn, and I suddenly knew why Landowska did not have a place on the marquee next to Harnoncourt, Leonhardt, and Brüggen (COHEN, 1985, p.25). ${ }^{23}$

As an advocate for the harpsichord, Landowska strongly resonates with period-instrument revivalist, but the state of her instrument unashamedly reflects a turn-ofthe-century performance aesthetic. Her Pleyel utilizes a sixteen-foot register, pedals for changing the stops, and leather plectra instead of quill - all housed within a sturdy metal frame. ${ }^{24}$ This metal monster stands in defiance to 1960s "authenticity," and still today the early twentieth-century sound distracts us from the quality of Landowska's music making.

The early music movement's aversion to Landowska's instrument is a symptom of what TARUSKIN (2009, p.13) would probably call Klangmaterialismus (sound fetish or infatuation), a term that he recently used to differentiate between Early Music and Alte Musik. ${ }^{25}$ Taruskin asserts that the term Early Music (which he affiliates with Stravinsky) signifies an infatuation with the details of the "sounding surface," such as timbre, texture, and articulation - all of which make up what the early music movement once called the "authentic" sound. He juxtaposes this approach against the term Alte Musik of Schoenberg and the Second Viennese School. Here, interpretation, using contemporary means, is conjured by digging deep "below the surface - to [get to] the 'subcutaneous' level, where motives lurk." (TARUSKIN, 2009, p.20) As a consequence of this paradigm, the Second Viennese School considers Alte Musik an extension of their present musical situation, while with Early Music, the "authenticity" movement aims to detach music of the past from the immediate present or from the not so immediate present, such as the nineteenth century.

Within this context, Landowska has one foot firmly placed in each camp. On a philosophical level, she challenges the idea of progress in music. Landowska argues that newer music was not superior to older music and period instruments significantly affect interpretation - situating Landowska within Early Music (LANDOWSKA, [1909] 1923, p.4-6). On the other hand (or foot), her hybrid instrument, which clearly reflects a contemporary performance aesthetic, aligns her with the Second Viennese School and the ideal of progress embodied in its concept of Alte Musik.

However, full membership for Landowska in either of these camps is unattainable. Her use of a harpsichord or non-modern instrument exposes to the Second Viennese School a blatant disconnection with the present while for the 1960s "authenticity" movement, the Pleyel too closely resembles a present-day monster. Therefore, Landowska holds a precarious place in our performance world. Her legacy is neither truly "authentic" nor truly modern. 


\section{5 - Haydn, Once Again}

Taking this all into account, I return to Landowska's recording and let Haydn's concerto have a full turn. Now more able to move past the sound of her instrument, I notice a few performance conventions made classic by the early music movement. Landowska takes more liberties with articulation and ornamentation in the Haydn performance. At the end of the harpsichord's opening statement in the first movement, a series of eighth notes marked without a slur are articulated in units of twos and threes, demarcated by the virtue of steps and skips. Here, Landowska adorns Haydn's music with her own paratext. ${ }^{26}$ Her approach to ornamentation is also more adventurous. At the end of the development section, she recomposes Haydn's skeletal cadence before embarking upon the recapitulation. ${ }^{27}$

Landowska's tendency to re-compose and significantly change articulations is not as evident in her performance of the Mozart concerto. Perhaps in the Haydn she felt less inhibited by the harpsichord, or maybe it has something to do with the composer. Haydn's concerto was in the repertoire of concert pianists, but the work and its composer did not carry the same performance baggage of the more renowned Mozart. In an interpretative sense, Haydn's concerto - a work less enveloped in an established performance tradition - was more available to a specialist performer. It was music ripe for reinterpretation.

We also might consider the work's designation of a period keyboard instrument on its Parisian print (1784) - Pour le Clavecin ou le Forte Piano. Perhaps the indication for a clavecin signified to Landowska what ethnomusicologists sometimes refer to as a sense of "other." ${ }^{28}$ The otherness of the harpsichord, and to some extent Haydn, provided relief from the dictates of the canon and engendered a broader range of possibilities for interpretation. In other words, Haydn's concerto for harpsichord, in regard to Landowska's interpretative possibilities, was more akin with the obscure music of the French harpsichordists rather than that of its canonized contemporary, Mozart.

Despite Landowska's unauthentic instrument, the Haydn performance sounds "historically informed." Landowska is HIP. Her style is modern and exhibits the traits of the geometrical style of Stravinsky - Taruskin's early-music style.

\section{6 - Frankenstein's Monster}

My experience with Landowska's recording of Haydn illuminates an inherent challenge in the study of early twentieth-century performance practice. Sonic engagement with a performance convention that greatly differs from our own challenges our musical taste. It is one thing to create an eighteenth-century performance by reading Johann Quantz's treatise or poring over a manuscript of J. S. Bach. These efforts employ a transformative process, which extracts the written text - Quantz's words or Bach's musical notation - and translates it into sound. The sonic result is involuntarily shaped by our own per- formance aesthetic. Due to the desire to create a compelling performance, the findings fit comfortably within the interpreter's performance ideal. Under these circumstances, it is improbable to render a personally offensive interpretation. There is little chance of reliving Victor Frankenstein's experience: "I have created a monster!"

However, the pursuit of early twentieth-century performance practice requires a slightly different approach, one that utilizes the study of recordings. A recording for the most part is sonically intact, and therefore its content is unaffected by our value judgment. ${ }^{29}$ We face the coldhard facts unearthed from a time capsule. Within these parameters, Landowska's recordings may challenge our own conventions. These recordings may reveal performances or instruments that are not only different from our own, but are in conflict with what we think is good music making. The study of recordings makes the creation of (or more accurately) the discovery of a monster more probable. Despite the risk of unearthing something undesirable, let us return to Landowska and the first part of her biography. ${ }^{30}$

\section{7 - To Paris}

Born in Warsaw, Landowska (1879-1959) acquired her taste for Musique ancienne early on; the conductor Artur Nikisch, after hearing her play a prelude and fugue from the Well-Tempered Clavier on the piano in 1893, affectionately dubbed her "the Bacchante." (RESTOUT, 1965, p.6) ${ }^{31}$ After studying with Jean Kleczyński and Aleksander Michalowski - both champions of Chopin's music - at the Warsaw Conservatory in 1896, she moved to Berlin to study composition with Heinrich Urban, where she frequented the conservatory's Musikinstrumenten-Museum with its vast collection of harpsichords. ${ }^{32}$

As a performer of both old and new music, Landowska's move to Paris in 1900 was advantageous on many fronts; she entered a musically vibrant, politically charged, socially liberated, and fully connected scene. Paris in the last quarter of the nineteenth century was a haven for modern music and the revival of early repertoire. Parisian concerts frequently juxtaposed Musique ancienne and Musique moderne. Rather than full-performances of works, these "miscellany concerts" programmed excerpts as part of an effort to reveal historical development. The works of Lully and Rameau were precious artifacts, hailing from a prestigious period in French culture. The musical dialogue between the old and the new - Dubois next to Lully, or Saint-Saëns following Rameau - portrayed contemporary music as an extension of a worthy lineage of composition. ${ }^{33}$ All of this resonated with a nation suffering from its devastating loss in the FrancoPrussian War. ${ }^{34}$ The miscellany concert was revised in the mid-1890s, when composers integrated these early forms and styles into their own compositions, referred to as neoclassicism. ${ }^{35}$ Therefore, it is not surprising that the earlymusic revival in Paris was led by a group of prominent composers and scholars including Vincent d'Indy, Gabriel 
Fauré, André Pirro, Albert Schweitzer, and Paul Dukas; their admiration for early music followed in the footsteps of Camille Saint-Saëns and César Franck. This synthesis of old and new music was cultivated in two institutions in Paris, the Paris Conservatoire and the Schola Cantorum. Early music had its most sympathetic place in the Schola, and this is where Landowska upon her arrival in Paris settled as a teacher of the harpsichord and piano. ${ }^{36}$

\section{8 - Ideology}

As with most Parisian institutions in the late-nineteenth century, the Conservatoire and the Schola were politically polarized by the Dreyfus Affair. In 1894 Alfred Dreyfus, a Jewish officer in the French artillery, was found guilty of selling military secrets to the Germans. He was exiled to the French Guiana, where he was placed in solitary confinement. A few years later, new evidence revealed that the traitor was Ferdinand Esterhazy, and there was a retrial. The military, however, suppressed this evidence and accused Dreyfus and others of fabrication. Dreyfus was sent back to South America worse off than before. The highly publicized efforts of left-wing politicians and artists, most notably Emile Zola, led to another trial and an eventual pardon of Dreyfus in $1899 .{ }^{37}$ But the damage had already been done, for the Dreyfus Affair was now part of the political, social, and cultural fabric of France. You were either with him or against him. ${ }^{38}$ Dreyfus's trials exposed a country grappling with nationalistic pride and anti-Semitism, and the grappling was evident in the Conservatoire and Schola. The Conservatoire aligned with the Republican government (Dreyfusard) while the Schola sided with the out-of-power right-wing Royalists (anti-Dreyfusard).

It was in direct opposition to the Dreyfusards that d'Indy, Bordes, and Alexandre Guilmant opened the Schola in 1894. ${ }^{39}$ D'Indy, an ardent Catholic, was influenced by Richard Wagner's writings on the decadence of nineteenthcentury opera. D'Indy attributed much of this decadence to the "insidious Jewish influence that had harmed so many aspects of different national cultures." (FULCHER, 1999, p.32) In the Schola, d'Indy brazenly mixed rightwing ideology (much of it anti-Semitic) with musical philosophy, and this infusion was reflected in the curriculum..$^{40}$ The Schola, committed to reviving plainchant and the sacred music of the Palestrina school, practically and theoretically enveloped its students in a Renaissance choral tradition, exemplified by Monteverdi and other Italian masters. The teaching of counterpoint and the performance of sacred polyphony were sympathetic with Royalist ideology and in opposition to the secular ideals of the Republic. The Schola's curriculum put off standard Conservatoire repertoire, such as opera, oratorio, and the cantata, until the fifth year. It also differentiated itself by eliminating the concours, for the French nobility had considered these public competitions undesirable displays of musical professionalism. ${ }^{41}$ Jann Pasler recently challenged the one-sided construction of d'Indy's legacy. She contends that the depiction of d'Indy and the Schola as a rigid right-winger and his side-car institution is not wholly accurate. Pasler points out that d'Indy worked with musicians and politicians from both the right and left (especially before 1900), nearly half of the professors at the Schola were prize winners at the Conservatoire, and both the Schola and Conservatoire shared numerous pedagogical principles and practices, such as end-term exams (PASLER, 2008, p.246). However, the rigidness of d'Indy's musical and political ideology, whether accurate or not, was affiliated with the Schola. ${ }^{42}$ Claude Debussy presumed the Schola to be right wing and, in 1903, was surprised by the institution's synthesis of old and new music with old and new politics:

It is a strange thing, but at the Schola, side by side, you will find
the aristocracy, the most left-wing of the bourgeoisie, refined ar-
tists, and coarse artisans (FULCHER, 1999, p.30).

While Albert Schweitzer's 1959 letter to Landowska exposes an apparent division between the Schola and the Conservatoire:

You yourself were associated with the Schola Cantorum. There was accordingly between us the gulf that existed between the Conservatoire and the Schola Cantorum. We crossed it (MURRAY, 1994, p.74). ${ }^{43}$

\section{9 - Madame Landowska ${ }^{44}$}

Despite her place in the Schola with its incommodious factions, Landowska was a modernist and part of the artistic elite of Paris. Her international performance career, her affiliation with the lesbian-writer Natalie Barney's Académie des Femmes, and her close personal relationships with other woman - two of whom lived in her home for many years - reveal her as a liberated individual.

Landowska frequently performed at Barney's literary soirées held in the Salon de l'Amazone on 20 Rue Jacob. ${ }^{45}$ One such occasion was a June 1910 theatrical performance of Le ton de Paris (LASCARIS, [1787] 1911), where from the second-floor bedroom Landowska played the music of Couperin on the harpsichord (RODRIGUEZ, 2002, p.194195). ${ }^{46}$ On this particular mid-summer evening, Landowska from her designated perch must have observed a fantastic spectacle, for Barney had, in conjunction with the theater performance, organized a masked ball in the garden. The garden - with its meandering path leading to a four-columned Doric eighteenth-century temple inscribed with the words Temple à l'Amitié (temple devoted to friendship) - was illuminated by Japanese lanterns. ${ }^{47}$ The costumed guests meandered through the wooded grounds. Barney's neighbor, the writer Jean de Bonnefon, donned the red robes of a cardinal; Paul Poiret, the so-called Picasso of fashion design, dressed as a Buddhist monk while the full-figured soprano Emma Calvé, lounging in a sedan chair, made a diva-like entrance carried by four exhausted porters. Barney, of course, would not be outdone. She dressed as a Japanese firefly chaser and carried a cachet of tiny light bulbs that posed as her captive insects. I am sure this exotic scene, reminiscent of Shakespeare's nocturnal comedy, was well complimented by the "otherness" of Landowska's instrument and its repertoire. 
Landowska's contributions to these occasions must have been significant, for her name is immortalized in Barney's hand-written map of her salon. ${ }^{48}$ On this rough sketch, Barney scribbled in the names of artists, writers, patrons, and musicians that frequented her salon - including her lovers. True to the art of a salonnière, her guests are strategically seated according to their shared interests. In the upper right-hand quadrant next to the table serving orangeade, fruit, port, and whisky, "Wanda Landowska" sits with "Virgil Thompson [sic]," "Darius Milhaud," "Antheil," and "Honegger"; they surround "Armande de Polignac," the niece of Prince Edmond, whose wife Winnaretta Singer was a patron of many of these composers. ${ }^{49}$ Barney's sketch, with its intertwined appellations, reflects the fully connected nature of Landowska's world. Landowska mixes and mingles with "T. S. Elliot," "Isadora Duncan," "RiIke," "Gertrude Stein," "Sinclair Lewis," and "Montesquiou Proust." She is of and among the artistic elite.

Landowska's affiliation with Barney and the writer's notoriously lesbian environs have brought forth speculation. W. G. ROGERS (1968, p.48) was adamant about her lesbianism. "[Barney] welcomed cordially [those who] shared her ways of intimacy [such as] Landowska." Landowska never formally admitted her sexual orientation, but her relationships with women - relationships that mixed professionalism with intimacy - have fueled suspicion. Patricia Juliana Smith, in her entry on Landowska in the Encyclopedia of Gay, Lesbian, Bi-Sexual, Transgender, and Queer Culture, contends that Landowska while living in Berlin organized a "ménage à trois" between her husband Henryk Lew and their housekeeper Elsa Schunicke. Landowska's housekeeper has been described by those closest to Landowska as "her most beloved and devoted companion." (RESTOUT, 1960, p.138) ${ }^{50}$ Due to Landowska's supposed lesbianism, Martin Nowak contends that Lew had a female lover while Smith adds that a competition existed between Landowska and Nadia Boulanger over the affections of their younger female students (NOWAK, 2009; SMITH). ${ }^{51}$ The lesbian community, citing Landowska's apparent openness about her sexuality with students and colleagues, has claimed her as one of their own. Martha Mockus goes one step further in Lesbian Histories and Culture. She claims to hear Landowska's sexual orientation and draws a metaphor between the struggle of lesbians in society and Landowska's efforts to gain equal status for the harpsichord in the mainstream-musical world:

Her performances of keyboard music were marked by a vigorous passion that is often considered excessive but can be heard as the work of a lesbian musician clearly devoted to promoting the beauty, subtlety, and status of the harpsichord in the classical-musical world (MOCKUS, 2000, p.435).

\section{0 - A Jew in the Schola}

Landowska's Jewish heritage and liberated social circles makes her decade-long affiliation with the anti-Semitic, right-wing Schola seem rather extraordinary. How did Landowska reconcile these differences? As with her sexual orientation, Landowska never formally spoke about her spirituality. However, anti-Semitic feminists were not unheard of in early twentieth-century Paris. Barney openly expressed anti-Semitism. Barney's biographer, Suzanne RODRIGUEZ (2002, p.312), attributes this phenomenon to the "zeitgeist of her time, a careless anti-Semitism." She contends that Barney protected herself from the incoming Nazis - citing the well-timed publishing of her most antiSemitic book Nouvelles pensées de l'Amazone (1939). ${ }^{52}$

Willa Silverman's research on Gyp (Sybille-Gabrielle de Riquetti de Mirabeau) - a feminist, anti-Semitic, anti-republican novelist and political activist during the Dreyfus Affair - also shows that a woman could be both antiSemitic and feminist (SILVERMAN, 1997). ${ }^{53}$ Gyp embodied sexual ambiguity and expressed, in caricature-like fashion, the image of a liberated Parisian woman. She was a crossdresser clothed in garments that accented her muscular arms and, at the same time, a grande dame of her salon, outfitted in luxurious frocks. ${ }^{54}$ Silverman wondered if "she [saw] herself as a man trapped in a woman's body?" (1997, p.19) Dreyfusards clearly knew what they saw; they depicted Gyp as a hideous creature - "a Walkyrie drinking human blood." (SILVERMAN, 1997, p.20) When Gyp was questioned about her profession, she infamously answered that she was not a writer, but rather an anti-Semite (SILVERMAN, 1997, p.13). ${ }^{55}$

Both Gyp's and Barney's lifestyles, paired with their seemingly contradicting political views, show that Landowska with her far-less sensational personal complexities comfortably fits in the political and social framework of the Schola. Regardless of whether Landowska was a lesbian, feminist, or anti-Semitic Jew - and whether there was a conflict of interest between any of these scenarios - Landowska found a receptive environment in the Schola to develop, refine, and realize her passion for early music and the harpsichord.

\section{1 - The Wonder of Wanda, "Hocus Pocusness"}

Landowska's favorable reputation as an interpreter of old and new music - for both the harpsichord and piano - spread throughout Paris's network of composers and their patrons. As reflected in Barney's sketch, Winnaretta Singer (Princesse Edmond de Polignac) was one such patron. She hosted performances of works by Chabrier, d'Indy, Debussy, Gabriel Fauré, and Maurice Ravel - and also commissioned emerging composers such as Stravinsky (Renard), Eric Satie (Socrate), and Darius Milhaud (Les Malheurs d'Orphée) (BROOKS, 1993; ROSS, 2006, p.108-110). At a 1923 performance in Polignac's saIon, Landowska played the harpsichord part for Manuel de Falla's El retablo de maese Pedro and attracted the attention of Francis Poulenc (Pablo Picasso and Stravinsky were also in attendance). ${ }^{56}$ This led to concerto commissions by Falla and Poulenc. ${ }^{57}$ The latter claimed that his engagement with Landowska on the Concert Champêtre was a turning point in his career. ${ }^{58}$ By the late 1920s, Landowska had acquired superstar status in Europe, and her reputation quickly spread beyond its 
borders with concerts in Russia and the United States (ZUCKERMANN, 1969, p.164). ${ }^{59}$

A particular aura surrounded Landowska. She cultivated an atmosphere that Ralph KIRKPATRICK (1985, p.68), at first impression, cynically referred to as "hocus pocusness." 60 And her recitals were bewitching. Drawing on the practice of the salons, Landowska's performances combined intimacy with showmanship. The lights dimmed, and she levitated over an ornate carpet to her harpsichord subtly illuminated by a floor lamp. (Many never actually saw her walk on stage; they claimed she just appeared next to the harpsichord.) Garbed in a red velvet robe, Landowska spoke profoundly and passionately about the music. Before she played a note, you were already entranced by her persona - taken in by the Wonder of Wanda. ${ }^{61}$ Even Landowska's detractors described her performances as transforming. KIRKPATRICK (1985, p.69) obviously found her personality challenging, but begrudgingly admitted that Landowska's performances of Mozart on the piano made him forget (at least temporarily) their personal differences. ${ }^{62}$

\section{2 - Influence}

Landowska was a musician of high repute, but her charismatic performance style and metal monster conflict with the objective and depersonalized ideals of 1960s "authenticity." Howard Mayer Brown's address to a 1978 conference for early-music performers and instrument makers, devoted to "The Future of Early Music in Britain," gives insight to Landowska's precarious position. ${ }^{63}$ Brown discusses the youthful state of the early music movement and the possible hazards of its imminent popularity:

\footnotetext{
Many would agree that early music should be presented to large audiences - we have seen that it can have broad appeal if it is properly explained and attractively performed - and yet no one should defend the kind of popularization that distorts or falsifies the music (BROWN, 1978, p.xiv).
}

Brown describes a movement emerging from a stage of adolescence and implores that "standards need to be improved" in preparation for adulthood or the mainstream (1978, p.xiii). Brown's view of the early twentieth-century early music movement is clearly blocked by "authenticity," for he does not consider the accomplishments of Landowska and her generation, whose musical standards, as we have seen, were improved enough. Landowska's generation is pre-history. It is a disconnected era.

Brown's trepidation over popularization is expected from an alternative movement entering the mainstream. ${ }^{64}$ Here the ideals of 1960s "authenticity," which emphasize the composer's intentions or the period instruments themselves as the influencers of style, are heard loud and clear. In some cases, the mere presence of historical instruments was a sign of better music making. ${ }^{65}$ Malcolm Bilson in 1980:

I have often heard it stated by scholars and others interested in performance on early instruments that they rather hear a great artist on the wrong instrument than a mediocre player on the right one. I am no longer willing to accept that statement. Perhaps it is wrong to put the instrument before the artist, but I have begun to feel that it must be done (BILSON, 1980, p.161).

The movement's orientation toward the composer and historically prescribed instruments deflects attention from the individual performer and makes the formal recognition of collegial influence unsavory. This explains why the acknowledgment of "historically informed" elements in the performance style of Landowska and her generation are scarce in the literature on the early music movement.

There is no shortage of biographical information on the early music movement (see COHEN and HASKELL [1996], SHERMAN [1997], ELSTE [2000], FABIAN [2003], GOLOMB [2004]), and HAYNES [2007]), but most biographies do not draw distinct connections between performers on stylistic grounds. Fabian and Golomb explore style lineage, but their research addresses primarily post-war performers. ${ }^{66}$ Why is the movement so hesitant to construct a stylistic stemma? Perhaps the formal recognition of collegial influence conflicts with the early music movement's authentistic philosophy - a philosophy only validated by historical reference. In other words: "I am historically informed" (not informed by my colleagues). Perhaps collegial influence is reminiscent of a previously conquered adversary - the stereo-typical nineteenth-century performance philosophy: "I play it like my teacher plays it." However, the presence of collegial influence is not entirely ignored by members in the early music movement, for Barthold Kuijken exposes influence from within the movement (1994). He criticizes the present generation's approach to historical investigation and points to an infatuation with the previous generation's recordings, performances, and literature. Kuijken portrays a generation ensnared in a trap, whose design is made possible by the early music movement's aim to become institutionalized and mainstream. His critique reveals collegial influence, but unfortunately puts it in less-than-ideal lighting.

\section{3 - In Pursuit}

As I mentioned at the onset of this paper, Taruskin believes that as early as 1907 Landowska introduced the geometrical style to Stravinsky. ${ }^{67}$ The centerpiece of his argument is Stravinsky's Pastorale, a work for voice and piano written in St. Petersburg in $1907 .{ }^{68}$ According to TARUSKIN (1996, p.365), this "little piece" - with its three-part counterpoint, "open and pervasively lined" texture, and continuous sixteenth notes in the left hand marked Sempre staccato - reveals Stravinsky's signature style for the first time. Taruskin proposes Landowska's tour of Russia in 1907 as a possible explanation for the emergence of Stravinsky's recognizable handwriting. The tour included performances in Moscow, Yasnaya Polyana (Leo Tolstoy's country residence), and St. Petersburg. ${ }^{69}$ Her recitals in St. Petersburg on 27 February and 22 March could have drawn Stravinsky's attendance, since he lived in St. Petersburg at the time. The recital in March, 
titled "The History of the Waltz," included works by Schubert, Schumann, and Chopin performed on the piano, but also featured Renaissance dances from Le trésor d'Orphée: Livre de tablature de luth (1600) by Anthoine Francisque. Landowska performed these pieces on the harpsichord and received mix reviews by the critic attending the performance. ${ }^{70}$ Francisques's collection contains rustic voltas and drone bases that, according to Taruskin, "conjure up a pastoral mood." One dance in the collection, the Branle di Montirandé, was a favorite of Tolstoy during Landowska's residence in Yasnaya Polyana (RESTOUT, 1967). ${ }^{71}$ Taruskin contends the pastoral traits in the Branles of Francisque's collection are evident in Stravinsky's Pastorale. ${ }^{72}$ To further support the Stravinsky-Landowska connection, Taruskin cites Landowska's programming of Joseph Lanner's Valses viennoises, of which the "Styrische Tanz" appeared four years later in Petrushka (LANNER, 1925; and TARUSKIN, 1996, p.367).

Landowska might have programmed her own compositions and arrangements of folk songs on this occasion. In fact, Landowska composed Berceuse during her 1907 residence in Yasnaya Polyana. ${ }^{73}$ This bi-sectional solopiano piece features an ostinato bass line, overlaid by a lyrical melody. In the second section, the left-hand ostinato is replaced by a chord progression with numerous open fifths and octaves. Landowska's Bourree d'Auvergne, an arrangement of dances she recorded later (as early as 1923), displays similar ostinato patterns and harmonic tendencies. ${ }^{74}$ Her performances of these works could have inspired a budding geometrist, such as Stravinsky.

\section{4 - Kleczyński's Chopin, Landowska's Couperin}

Perhaps Jean Kleczyński and his treatise, The Works of Frederic Chopin and their Proper Interpretation ([1879] 1913), inspired a young Landowska. ${ }^{75}$ As a student of Kleczyński in the Warsaw Conservatory, Landowska must have easily absorbed his ideas on performance. Landowska's openness to him is evidenced by Kleczyński's observation of her playing: "This child is a genius!" (RESTOUT, 1965, p.6) ${ }^{76}$ The Works of Frederic Chopin and their Proper Interpretation gives insight to Landowska's early influences and stylistically and philosophically connects Kleczyński - via his famous student - to the early music movement.

Kleczyński describes Chopin's performance style as rational and emotionally balanced, in clear opposition to the Romantic "convulsions" of his time:

\footnotetext{
Chopin never loses the feeling of equilibrium; always refined, he feels that passion should never descend to the prose of realism. He suffers, he has his fits of madness, but none of those unbecoming convulsions which composers of the present time, sometimes without reason or sense, introduce into their realistic productions (KLECZYŃSKI, [1879] 1913, p.13).
}

In 1909, Landowska reiterated Kleczyński's comments on Chopin and associated the composer with Couperin, dra- wing a connection between the performance style of Baroque repertoire and that of Poland's most famous pianist:

And later, in the midst of the Romantic epoch, we find Chopin who, like a resurrected Couperin, rejected every tonal violence, all pianistic din (KLECZYŃSKI, [1909] 1923, p.44, 156). ${ }^{77}$

Kleczyński cites misinterpretations of Chopin's music, such as exaggerations in rubato and "the turning of the thought upside down," due to the overemphasis of weaker notes in the measure ([1879] 1913, p.18). His commentary is kindred to the early music movement's adherence to an unchanging pulse and proper beat hierarchy. ${ }^{78}$

Kleczyński also illustrates the proper phrasing for Chopin's music. His examples prescribe at cadences the typical early-music diminuendo paired with the literal halving of the last note (replaced with a rest). This convention, in contrast to long-line phrasing, reduces the overarching phrase unit into small cells - highlighting smaller structures within a larger one ([1879] 1913, p.50-51). Harnoncourt believes the origins of long-line phrasing lie at the Paris Conservatoire in the nineteenth century (1988, p.25). Geoffrey Burgess concurs with Harnoncourt and brings to light phrase revisions in older vocalizes by the Conservatoire's oboe professor, Gustave Vogt (BURGESS, 2003, p.41-43). His revisions reveal a predilection for long-line phrasing in mid-nineteenthcentury Paris. ${ }^{79}$ However, Kleczyński, who lived in Paris in the early 1860 s, describes a phrasing more aligned with the cellular conventions commonly attributed to the modernist performance style of the early music movement. ${ }^{80}$

\section{5 - A Shared Rhetoric}

In The Works of Frederic Chopin and their Proper Interpretation, Kleczyński employs an anti-other rhetoric that aims to restore and purify Chopin's performance style. The nature of this rhetoric - one that lays blame on a group, era, or movement for distorting the composer's original intentions - has been frequently adopted and adapted by members of the early music movement from the last quarter of the nineteenth century throughout the 1980s. The only difference is the guilty party.

In 1879, Kleczyński [quoting M. Wilcznski] juxtaposed the simple and pure Slavonic aesthetic against Germanic barbarity:

The country of the Germans is built upon a barbarous model; it inspires a superstitious fear which penetrates you from every point of view... Our land, on the contrary, breathes calmness and tranquility... Our style aspires to two ruling qualities: simplicity and purity (KLECZYŃSKI, [1879] 1913, p.68-69).

At the turn of the century, d'Indy as editor of the Rameau Edition (1900) compared nineteenth-century alterations in eighteenth-century orchestra parts to the falsification of evidence by the Jewish people in the Dreyfus Affair. Here, d'Indy's use of "twice" is a derogatory reference to the retrial of Dreyfus (twice trialed) that established the fabrication of evidence: 
And above all, don't trust the parts held by the Opera! They have been falsified, perverted, tarted up no more or less than the records of Dreyfus's trial by the good Semites... I have been forced to begin Hippolyte et Aricie again twice (THOMSON, 1996, p.95).

In 1909, Landowska blamed opera and revealed her disdain for the generous attention given to the genre:

\begin{abstract}
It is to be noted that in every age superior minds showed little enthusiasm for music with stage devices... It must be recognized that in the opera the music is diluted by the action, by the scenery. It is as if you watered the champagne served [to] a great connoisseur of wines (LANDOWSKA, [1909] 1923, p.53-54).
\end{abstract}

In 1915, Arnold Dolmetsch condemned modernity for the corruption of musical meaning:

It is advisable, however, before beginning this study, to clear our mind of prejudice and preconceived ideas and put aside intolerant modernity or else we may, as others have done, corrupt and twist about the meaning of even the clearest statement (DOLMETSCH, 1915, p.xiv).

Harnoncourt, in 1968, made the Romantic tradition the elephant in the room:

An interpretation must be attempted in which the entire Romantic tradition of performance is ignored (HARNONCOURT, 1968).

And in 1974, Brüggen optimistically sensed the nineteenth century leaving the room:

It's already clear that the usual form of concert recital, where one takes a bow and nonsense like that, will be gone in a couple of years. So then we will have the last remaining traces of the nineteenth century behind us. I hope so! (BRÜGGEN, 1974, p.103)

While Roger Norrington, in 1987, set out to rescue Beethoven from a dehumanized complacency:

In particular, we want to restore the Ninth Symphony to the humane, quicksilver thought-world of the Classical Period (NORRINGTON, 1987).

Members of the "authenticity" movement, in an effort to defend their style of performance, embraced a rhetorical device that established an air of exclusivity, superiority, and righteousness. This rhetoric predates the 1960s "authenticity" era. Kleczyński's, d'Indy's, and Landowska's efforts to restore and purify performance connects them to the "modern" early music movement of Brüggen, Harnoncourt, and Norrington.

\section{6 - Full Circle}

It is time to bring Landowska back into the fold and, ironically, the notion that negated her role in the first place, "authenticity," is the path by which she may very well return. The notion of "authenticity" employed by Landowska, Kleczyński, and d'Indy was less rigid than the 1960s variety. Kleczyński strongly advocated for an authentic rendering of Chopin's music, but at the same time acknowledged with the composer's death that Chopin's style is unattainable (KLECZYŃSKI, [1879] 1913, p.6162). D'Indy's additions of wind and inner-string parts to Rameau's Hippolyte et Aricie (1900)- left conspicuously unmentioned in the 135-page preface to the edition (despite his remarks about perversions to the performance parts) - expose a desire to enhance eighteenth-century music when it did not quite play up to his expectations (SADLER, 1993, p.416). Landowska, in a paranormal reference to Rameau, takes Kleczyński's sentiment and d'Indy's textual embellishments one step further:

\section{If Rameau himself would rise from his grave to demand of me some changes in my interpretation of his Dauphine, I would answer, "You gave birth to it; it is beautiful. But now leave me alone with it. You have nothing more to say; go away!" (RESTOUT, 1965, p.407)}

Compare Landowska's statement with one made recently by the early-music specialist Rene Jacobs - "I don't feel I have to reproduce how things were done in the past. I reimagine them" - and it seems that a new sort of "authenticity" has emerged. Or more accurately, an old one has returned (quoted in WHITE, 2006).

The post-"authenticity" early music movement embraces a myriad of performance philosophies, ideals, and practices. This is reflected in Joshua Rifkin's recent appraisal of the movement in Goldberg Magazine:

[The early-music] world has grown large enough to encompass all the contradictions, the flaws and the virtues, of any substantial and mature culture. So we don't have a panacea. But we have room for all - "strict constructionists," the wild and willful, and everything in between... We do have a lot to celebrate (RIFKIN, 2008, p.21).

The early music movement is moving in a cosmopolitan direction, one more aligned with Michelle Dulak's "postmodern performance practice" (DULAK, 1993, p.61). ${ }^{81}$ As early as 1993, Dulak sensed a "metamorphosis" within the movement (DULAK, 1993, p.61). The collaborations between modern and early-music musicians since the late 1980s, such as Yo-Yo Ma and the Amsterdam Baroque Orchestra (1999), Cecilia Bartoli and II Giardino Armonico (1999), and The Orchestra of the Age of Enlightenment with Simon Rattle (REES, 2010), confirm her suspicion. While modern-instrument organizations that specialize in early repertoire, such as Combattimento Consort Amsterdam (CCA) and the weekly Bach cantata series presented in Boston's Emmanuel Church (EMMANUEL), valiantly carry on the nineteenth-century efforts of Choron and Bordes. ${ }^{82}$

In the field of musicology, "authenticity" has resurfaced in an enlightened guise. In an effort to pry off those pesky quotation marks, John Butt's Playing with History: The Historical Approach to Musical Performance (2002) and Peter Walls's History, Imagination, and the Performance of Music (2003) astutely reevaluate the role historical truth plays in performance. ${ }^{83}$ The books' titles alone reflect a more flexible approach that openly plays with the idea of historical imagination. Even Taruskin noticed changes. Andrew Manze's imaginatively vivid recording (MANZE, 1997) of Giuseppe Tartini's The Devil's Sonata inspired him to write, "It is one of the most encouraging defiances of late-late romantic taste I've heard in years" (TARUSKIN, 2006, p.131). 
Unexpected early-music performers, such as Sting, are also staking their claim. Sting's most recent collaboration with lutenist Edin Karamazov in a recording of John Dowland songs has set the movement abuzz (STING, 2006). ${ }^{84}$ Sting also plays Bach on the Classical guitar. In 2008, he produced a video short where Allessandra Ferri, principal dancer of the American Ballet Theater, dances to Sting's transcription of the First Cello Suite (STING, 2008). In this video, ballet is paired with a shirtless rock star performing Baroque counterpoint; three consecutive centuries coalesce in one production.

All of this has enticed Tess Knighton, then editor of the journal Early Music, to put forth the question: "So, are we indeed coming full circle? Is the relationship between periphery (or specialist) and mainstream an ever-repeating cycle of breaking away and reabsorption?" (KNIGHTON, 2006, p.531) ${ }^{85}$ We might also ask ourselves do the doctrines established by the gurus of the "authenticity" movement still hold true. What defines early music today: is it repertoire, instrumentation, style, intention ${ }^{86}$ And in what proportion do we mix these ingredients to make the cocktail we all call the early music movement?
In light of these developments, it is time to reabsorb and celebrate the contributions made by Landowska and other members of the early music movement before the "authenticity" era. As we settle comfortably into the twenty-first century and "authenticity" with its ensuing hangover is farther adrift, we might take a closer look at the beginning of the previous century and earlier. There, with our clearer head and less-obstructed view, we will find early-music experts - artists such as Landowska, d'Indy, and perhaps even Chopin's champion, Kleczyński - whose influence, despite their unauthentic instruments, is still present. As Cohen admitted, "Landowska seems closer to the true spirit of [early] repertories than many a player of the generation that came after." (COHEN, 1985, p.26)

Perhaps the early music movement has come full circle.

I am most grateful to Victor Coelho and Joshua Rifkin for their expert guidance during my work on this paper.

\section{Referências}

ALDRICH, Putnam. Wanda Landowska's Musique ancienne. Notes 27, no. 3 (Mar. 1971): p.461-468.

ANTHEIL, George. Bad Boy of Music. Garden City, New York: Doubleday, Doran \&t Company, 1945.

AUBERT, Laurent. The Music of the Other: New Challenges for Ethnomusicology in a Global Age [2001], translated by Carlo Ribeiro. Burlington VT: Ashgate, 2007.

ATTIE, Barbara, Janet Goldwater, and Diane Pontius. Wanda Landowska: Uncommon Visionary, DVD, Produced by Barbara Attie. Pleasantville, NY: Video Artists International, 1997.

BACH-CANTATAS.COM. Combattimento Consort Amsterdam (Instrumental Ensemble). http://www.bach-cantatas.com/ Bio/CCA.htm (accessed Jan. 21, 2010).

BARNEY, Natalie Clifford. Aventures de I'Esprit. Paris: Emile-Paul Frères, 1929.

BARTOLI, Cecilia, soprano, II Giardino Armonico. The Vivaldi Album. Decca B00002CF52. 1999. Compact disc. . Nouvelles pensées de l'Amazone. Paris: Mercure de France, 1939.

BATTAULT, Jean-Claude. Les clavecins Pleyel, Érard et Gaveau, 1889-1970. In Musique ancienne - Instruments et Imagination; Music of the Past - Instruments and Imagination. Actes Des Rencontres Internationales Harmoniques 2004; Proceedings of the 'Harmoniques' International Congress 2004, edited by Michael Latcham, p.193-212. Berne: Peter Lang SA, 2006.

BEGLEY, Louis. Why the Dreyfus Affair Matters. New Haven and London: Yale University Press, 2009.

BENSTOCK, Shari. Women of the Left Bank: Paris, 1900-1940. Austin: University of Texas Press, 1986.

BILSON, Malcolm. The Viennese Fortepiano of the Late Eighteenth Century. Early Music 8, no. 2 (April, 1980): p.158-162.

BR00KS, Jeanice. Nadia Boulanger and the Salon of the Princesse de Polignac. Journal of the American Musicological Society 46, no. 3 (Autumn, 1993): p.415-468.

BROWN, Howard Mayer. The Future of Early Music in Britain, edited by J. M. Thomson, xiii-xv. Oxford: Oxford University Press, 1978.

BRÜGGEN, Frans. Frans Brueggen on the Baroque Recorder. Early Music 2, no. 2 (Apr.1974): p.101-103. 
BURGESS, Geoffrey. The Premier Oboist of Europe: A Portrait of Gustave Vogt. Lanham, Maryland and Oxford: The Scarecrow Press, 2003.

BUT, John. Bach in the Twenty-First Century: Re-evaluating Him from the Perspective of Performance. Bach Studies from Dublin, edited by Anne Leahy and Yo Tomita, p.191-204. Irish Musical Studies 8. Dublin: Four Court Press, 2004.

. Historical Instruments and the Embodiment of Music. In Musique ancienne - Instruments et Imagination; Music of the Past - Instruments and Imagination. Actes Des Rencontres Internationales Harmoniques 2004; Proceedings of the 'Harmoniques' International Congress 2004, edited by Michael Latcham, p.9-16. Berne: Peter Lang SA, 2006.

Playing with History: The Historical Approach to Musical Performance. New York: Cambridge University Press, 2002.

CARHART, Thad. Schola Cantorum. Chap. 16 in The Piano Shop on the Left Bank. New York: Random House Inc., 2001.

CARROLL, David. French Literary Fascism: Nationalism, Anti-Semitism, and the Ideology of Culture. Princeton: Princeton University Press, 1995.

CASH, Alice H. Wanda Landowska and the Revival of the Harpsichord: A Reassessment. Ph.D. dissertation, University of Kentucky, 1990.

Wanda Landowska and the Revival of the Harpsichord. In Music in the Theater, Church, and Villa: Essays in Honor of Robert Lamar Weaver and Norma Wright Weaver, edited by Susan Parisi, p.277-284. Michigan: Harmonie Park Press, 2000.

CCA. Combattimento Consort Amsterdam. http://www.combattimentoconsort.com (accessed November 2, 2010).

CHARLE, Christophe. Noblesses et élites en France au début du XXe siècle. In Noblesses Européens au XIXe siècle. Paris: Collection de l'Ecole Française de Rome 107, 1988.

COHEN, Joel, and Herb Snitzer. Reprise: The Extraordinary Revival of Early Music. Boston: Little, Brown \&t Company, 1985.

COLDWELL, Maria. Long Live 'Globalization'. Goldberg 50 (Feb. 2008): p.25.

Early Music in America: A Study of Early Music Performers, Listeners, and Organizations. Seattle: Early Music America, 2005.

DAY, Timothy. A Century of Recorded Music: Listening to Musical History. New Haven and London: Yale University Press, 2002.

DEMUTH, Norman. Vincent d'Indy (1851-1931): Champion of Classicism. Westport, Connecticut: Greenwood Press, 1951.

DENNIS, Nigel. Manuel de Falla, John B. Trend: Epistolario: 1919-1935. Granada: Universidad de Granada, 2007.

DICKINSON, C. Appreciations of Alexandre Guilmant. The Musician 16 (1911): p.488.

DOLMETSCH, Arnold. The Interpretation of Early Music of the Seventeenth and Eighteenth Centuries Revealed by Contemporary Evidence. London: Novello, 1915.

DOWD, Phillip Michael. Charles Bordes and the Schola Cantorum of Paris: Their Influence on the Liturgical Music of the Nineteenth and Early Twentieth Centuries. Ph.D. dissertation. The Catholic University of America, 1969.

DREYFUS, Richard. Early Music Defended against its Devotees: A Theory of Historical Performance in the Twentieth Century. The Musical Quarterly 69, no. 3 (1983): p.297-322.

DROYSEN-REBER, Dagmar, Martin Elste, and Hannelore Schneider, compilers. 100 Jahre Berliner Musikinstrumenten Museum: 1888-1988. Berlin: Staatliches Institut für Musikforschung Preussischer Kulturbesitz, 1988.

DULAK, Michelle. The Quiet Metamorphosis of 'Early Music'. Repercussions 2 (Fall 1993): p.31-61.

EIGELDINGER, Jean-Jacques. Wanda Landowska: Situation historique, position artistique. In Musique ancienne - Instruments et Imagination; Music of the Past - Instruments and Imagination. Actes Des Rencontres Internationales Harmoniques 2004; Proceedings of the 'Harmoniques' International Congress 2004, edited by Michael Latcham, p.213-238. Berne: Peter Lang SA, 2006.

ELLIS, Katherine. Interpreting the Musical Past: Early Music in Nineteenth-Century France. Oxford: Oxford University Press, 2005.

Vocal Training at the Paris Conservatoire and the Choir Schools of Alexandre-Etienne Choron: Debates, Rivalries, and Consequences. In Musical Education in Europe (1770-1914): Compositional, Institutional, and Political Challenges, vol. 1. Edited by Michael Fend and Michel Noiray, p.125-144. Musical Life in Europe 1600-1900: Circulation, Institutions, Representation. Berlin: Berliner Wissenschaft-Verlag, 2005a.

ELSTE, Martin. Die Dame mit dem Clavecin: Wanda Landowska. In Meilensteine der Bach-Interpretation 1750-2000: Eine Werkgeschichte im Wandel, p.337-339. Kassel: Bärenreiter, 2000. editor. Die Dame mit dem Cembalo: Wanda Landowska und die Alte Musik. Mainz: Schott, 2010.

editor. Modern Harpsichord Music: A Discography. Westport CT and London: Greenwood Press, 1995.

EMANUEL. Emanuel Music. http://www.emmanuelmusic.org (accessed Jan. 22, 2010). 
ENCYCLOPEDIA OF GAY, LESBIAN, BI-SEXUAL, TRANSGENDER, AND QUEER CULTURE. s.v. Wanda Landowska, by Patricia Juliana Smith. http://www.glbtq.com/arts/landowska_w.html (accessed Jan. 20, 2010).

FABIAN, Dorottya. Bach Performance Practice, 1945-1975. Burlington VT: Ashgate, 2003.

Bach Performance Practice in the Twentieth Century: Recordings, Reviews and Reception. In Bach Studies from Dublin, edited by Anne Leahy and Yo Tomita, p.179-189. Irish Musical Studies. Dublin: Four Courts Press, 2004.

The Meaning of Authenticity and the Early Music Movement: A Historical Review. International Review of the Aesthetics and Sociology of Music 32, no 2 (2001): p.153-167.

FAUSER, Annegret. Creating Madame Landowska. Woman in Music 10 (2006). http://muse.jhu.edu/login?uri=/journals/ women_and_music/v010/10.1fauser.html (accessed November 19, 2009).

Musical Encounters at the 1889 Paris World's Fair. Rochester, NY: University of Rochester Press, 2005.

FLINT, Catrena M. The Schola Cantorum: Early Music and the French Political Culture from 1894 to 1914. Ph.D. dissertation, McGill University, 2006.

FORTH, Christopher. The Dreyfus Affair and the Crisis of French Manhood. The Johns Hopkins University Studies in Historical and Political Science 121. Baltimore and London: The Johns Hopkins University Press, 2004.

FRASCINA, Francis, and Charles Harrison, eds. Modern Art and Modernism: A Critical Anthology. New York: Harper and Row, 1982.

FRANCISQUE, Antoine. Le Trésor d'Orphée [Facs.]. Genève: Minkoff, 1973.

Le Trésor d'Orphée d'Antoine Francisque, transcribed for piano by Henri Quittard. Paris: L.-Marcel Fortin \&t Cie, 1906.

FULCHER, Jane F. French Cultural Politics and Music: From the Dreyfus Affair to the First World War. New York and Oxford: Oxford University Press, 1999.

.The Composer as Intellectual: Music and Ideology in France 1914-1940. 0xford: Oxford University Press, 2005.

FURTWÄNGLER, Wilhelm, conductor. Fifth Brandenburg Concerto. Vienna Philharmonic at the Salzburg Festival [1950]. EMI B00004UB81. 2005. Compact disc.

GAVOTY, Bernard, and Roger Hauert. Wanda Landowska, Great Concert Artists. Geneva: René Kister, 1957.

GOLOMB, Uri. Expression and Meaning in Bach Performance and Reception: An Examination of the B Minor Mass on Record. Ph.D. dissertation, Cambridge: King's College Cambridge, 2004.

HARNONCOURT, Nikolaus, conductor,Gustav Leonhardt, conductor, Concentus Musicus Wien, and Leonhardt-Consort. Bach: Das Kantatenwerk. Telefunken and Teldec. 1971-1989. LP and Compact disc.

HARNONCOURT, Nikolaus. Liner notes for J. S. Bach B Minor Mass. Telefunken 6.35620 FD. 1968. LP.

Baroque Music Today: Music as Speech: Ways to a New Understanding of Music [1982], translated by Mary O'Neill. Portland, OR: Amadeus Press, 1988.

HARTWELL, Robin. Postmodernism and Art Music. In The Last Post: Music after Modernism, edited by Simon Miller, p.2751. Music and Society. New York: Manchester University Press, 1993.

HASKELL, Harry. The Early Music Revival: A History. New York: Dover Publications Inc., 1996.

HAYDN, Joseph. Concerto Pour le Clavecin ou le Forte Piano avec Accompagnement. Paris: Boyer, 1784.

Kritischer Bericht. In Konzerte für Klavier (Cembalo) und Orchester (vol. 15, no. 2), edited by Horst Walter and Bettina Wackernagel, p.169-200. Munich: G. Henle Verlage: 1983.

HAYNES, Bruce. The End of Early Music: A Period Performer's History of Music for the Twenty-First Century. 0xford: 0xford University Press, 2007.

HESS, Carol A. El retablo de Maese Pedro: Falla's Reading of the Quijote. In Manuel de Falla and Modernism in Spain, 1898-1936, p.199-231. Chicago: University of Chicago Press, 2001.

Sacred Passions: The Life and Music of Manuel de Falla. New York: Oxford University Press, 2005.

HILL, Edward Burlingame. Vincent d'Indy: An Estimate. The Musical Quarterly 1, no. 2 (Apr. 1915): p.246-259.

HINDEMITH, Paul. Johann Sebastian Bach: Heritage and Obligation. London: Oxford University Press; New Haven: Yale University Press, 1952.

HOGWOOD, Christopher, conductor. Pachelbel Kanon and the Music of Handel, Vivaldi, and Gluck. New York: Editions de I'Oiseau-Lyre, 1981. LP.

HOGW00D, Christopher, conductor, Jaap Schröder, concert master, and The Academy of Ancient Music. Mozart: The Symphonies [1979-1982]. Decca B000004CYS. 1997. Compact disc.

HOLOMAN, D. Kern. The Société des Concerts due Conservatoire, 1828-1967. Berkeley: University of California Press, 2004. HOWARD, Michael. The Franco-Prussian War: The German Invasion of France 1870-1871. New York: Routledge, 2001. 
HULME, T. E. Modern Art and its Philosophy. In Speculations: Essays on Humanism and the Philosophy of Art, edited by Herbert Read, p.75-109. London: Routledge \& Kegan Paul, 1924.

IVRY, Benjamin. Francis Poulenc. London: Phaiden Press, 1996.

D'INDY, Vincent. La Schola Cantorum: Son Histoire depuis sa fondation jusqu'en 1925. Paris: Bloud et Gay, 1927.

JULLIEN, Adolph, and Gustave Ferrari. Paul Marie Théodore Vincent d'Indy. In Grove's Dictionary of Music and Musicians Vol. II, edited by J. A. Fuller, Maitland, p.465-466. Philadelphia: Theodore Presser Company, 1915, c1906.

KAHAN, Sylvia. Music's Modern Muse: A Life of Winnaretta Singer, Princesse de Polignac. Eastman Studies in Music 22. Rochester: University of Rochester Press, 2003.

KECK, George R. Francis Poulenc: A Bio-Bibliography. Bio-Bibliographies in Music 28. New York, London, and Westport, CT: Greenwood Press, 1990.

KELLY, Thomas. Early Music in America: A Report on a Survey Conducted by Early Music America. New York: Early Music America, 1989.

KENYON, Nicholas, editor. Authenticity and Early Music: Some Issues and Questions. Oxford: Oxford University Press, 1988.

KERMAN, Joseph, Laurence Dreyfus, Richard Taruskin, Joshua Kosman, John Rockwell, and Ellen Rosand. The Early Music Debate: Ancients, Moderns, Postmoderns. The Journal of Musicology 10, no. 1 (Winter, 1992): p.113-130.

KIRKPATRICK, Meredith. Ralph Kirkpatrick: A Bibliography and Discography. Boston University. http://www.bu.edu/ library/music/ralphkirkpatrick.htm (accessed Oct. 4, 2010).

KIRKPATRICK, Ralph. Early Years. New York: Peter Lang, 1985.

KLECZYŃSKI, Jean. The Works of Frederic Chopin and their Proper Interpretation [1879], translated by Alfred Whittingham. London: William Reeves, 1913.

KNIGHTON, Tess. Editorial. Early Music 34, no. 4 (Nov. 2006): p.531.

KOTTICK, Edward L. A History of the Harpsichord. Bloomington \&t Indianapolis: Indiana University Press, 2003.

KUIJKEN, Bartold. Auf Originalinstrumenten...historisch getreu?: Bemerkungen zur 'modernen' historischen Aufführungspraxis alter Musik. Tibia 19, no. 4 (1994): p.280-283.

LANDOWSKA, Wanda. Advice on the Interpretation of Chopin [L'Interprétation de Chopin, 1910], translated by Florence Leonard. Etude Music Magazine (Feb. 1926): p.407-408.

. Bach et ses interprètes: Sur l'interpretation des Oeuvres de Clavecin de J.S. Bach. Paris: Mercure de France, 1905.

. Chopin et l'ancienne musique française. La Revue Musicale 121 (Dec. 1931).

, harpsichord/piano. WA Mozart Coronation Concerto, FJ Haydn Concerto in D. In Treasury of Immortal Performances. Walter Goehr and Eugéne Bigot (conductors), RCA E1RP-0285-6. 1937. LP.

. The Music of the Past [Musique ancienne. Paris: Mercure de France, 1909], translated by William Aspenwall Bradley. New York: Alfred A. Knopf, 1923.

. Tolstoi musicien. Musica 7, no. 69 (June, 1908a): p.95.

. Une visite à la Comtesse Tolstoi. Femina 8, no. 180 (July 15, 1908): p.322-323.

LANNER, Joseph. Valses viennoises de Lanner, edited by Wanda Landowska. New York: Schirmer, 1925.

LASCARIS, Théodre, August Rondel, and Armand-Louis de Gontaut Lauzun. Le ton de Paris ou les amants de bonne compagnie: comédie en 2 actes [1787]. Paris: Champion, 1911.

LATCHAM, Michael. Don Quixote and Wanda Landowska: Bells and Pleyels. Early Music 34, no.1 (Feb. 2006): p.95-110.

LINDEMANN, Albert S. The Jew Accused: Three Anti-Semitic Affairs (Dreyfus, Geilis, Frank) 1894-1915. Cambridge: Cambridge University Press, 1991.

LISZNIEWSKI, Karol. Vintage Wanda Landowska Harpsichord Home Movie 1927. YouTube. http://www.youtube.com/ watch?v=YyBdS3DLTVY (accessed October 20, 2010).

MA, Yo-Yo, cello, Ton Koopman, director, and Amsterdam Baroque Orchestra. Simply Baroque. Sony B00000I0W. 1999. Compact disc.

MANZE, Andrew, solo violin. Tartini: The Devil's Sonata and Other Works. Harmonia Mundi France HMU907213. 1997. Compact disc.

MARCHWICA, Wojciech Maria. The Virtuosity and Aesthetic Beliefs of Wanda Landowska. In Affetti musicologici. Księga pamiątkowa z afektem ofiarowana Profesorowi Zygmuntowi Marianowi Szweykowskiemu w 70. rocznic urodzin / Affetti musicologici. Book of Essays in Honour of Professor Zygmunt Marian Szweykowski for his 70th Birthday, p.441-450. Kraków: Musica lagollenica, 1999. 
MARTY, Daniel. Une Dame Nommée Wanda: Wanda Landowska. Saint-Leu-la-Forêt: Association Les Amis de Wanda Landowska, 2008.

MELZER, Galia, and Michael Melzer. Musical Experience through the Authentic Approach, or, the Modernization of Early Music. Music in Time (1994): p.37-63.

MEYER, Stephen. Technology and Aesthetics: Historically Informed Performance Practice and the Compact Disc. In Performance Practice: Issues and Approaches, edited by Timothy D. Watkins, p.245-260. Ann Arbor, MI: Steglein Publishing, 2009.

MICHALOWSKI, Kornel. Polish Music Literature: 1515-1990, edited by Wanda Wilk. Polish Music History Series 4. Los Angeles: Friends of Polish Music, University of Southern California, 1991.

MOCKUS, Martha. Landowska, Wanda (1879-1959). Lesbian Histories and Cultures, edited by Bonnie Zimmerman. New York and London: Garland Publishing Inc., 2000.

MURRAY, Michael. Albert Schweitzer: Musician. Vermont: Ashgate Publishing Company, 1994.

NORRINGTON, Roger. Liner notes for Beethoven, Symphony No. 9 in D Minor. EMI CDC7492212. 1987. LP.

NORRINGTON, Roger, conductor, and The London Classical Players. Beethoven: 9 Symphonies [1989]. Angel Records B000002RRB. 1990. Compact Disc.

NOWAK, Martin. Madame Landowska (1879-1859): Harpsichordist and Socialite. Polishsite: Website about Polish Culture. http://www.polishsite.us/index.php/culture-and-tradition/music/403-madame-landowska-1879-1959-harpsichordist-a-socialite-.html (accessed March 11, 2010).

PAHISSA, Jaime. Manuel de Falla: His Life and Works, translated by Jean Wagstaff. Westport CT: Hyperion Press Inc., 1954.

PAHLEN, Kurt. Manuel de Falla und die Musik in Spanien. Mainz: Schott, 1994.

PALMER, Larry. Harpsichord in America: A Twentieth-Century Revival. Bloomington and Indianapolis: Indiana University Press, 1989.

PASLER, Jann. Composing the Citizen: Music as Public Utility in Third Republic France. Berkeley: University of California Press, 2009.

Deconstructing d'Indy, or the Problem of a Composer's Reputation. In Writing through Music: Essays on Music, Culture and Politics. Oxford and New York: Oxford University Press, 2008.

PEYSER, Herbert, F., and Pitts Sanborn. Wanda Landowska. Paris: G Cadel \&t Fils, 1925.

PHILIP, Robert. Early Recordings and Musical Style: Changing Tastes in Instrumental Performance 1900-1950 [1992]. Cambridge: Cambridge University Press, 2004.

Performing in the Age of Recording. Cambridge: Cambridge University Press, 2004.

Pianists on Record in the Early Twentieth Century. In The Cambridge Companion to The Piano, edited by David Rowland, p.75-96. Cambridge: Cambridge University Press, 1998.

QUANTZ, Johann Joachim. On Playing the Flute [Versuch einer Anweisung die Flöte traversière zu spielen, 1752], translated and edited by Edward R. Reilly. Boston: Northeastern University Press, 2001.

RAMEAU, Jean-Philippe. Hippolyte et Aricie. In OEuvres completes. Paris: Durand, 1900.

REDLICH, Hans Ferdinand. L'Orfeo: favola pastorale. Zurich: Buchdruckerei P. Hess, 1936.

Claudio Monteverdi. London: Oxford University Press, 1952.

REES, Jasper, interviewer. Theartsdesk Q\&A Special : The Conductor Simon Rattle. July 30, 2010 [Interview of Simon Rattle]. The Arts Desk. http://www.theartsdesk.com/index.php?option=com_k2\&tview=item\&tid=1927:sir-simon-rattleinterview\&tltemid=80 (accessed 0ct. 24, 2010).

REINER, Fritz, conductor, and Columbia String Ensemble. Brandenburg Concerto No. 5 in D Major [1949]. Columbia ML4283. Rereleased on Membrane Music Ltd. LC12281. 2005. Compact disc.

RESTOUT, Denise, and Robert Hawkins, editors. Landowska on Music. New York: Stein and Day, 1965.

RESTOUT, Denise. Mamusia: Vignettes of Wanda Landowska. High Fidelity (Oct. 1960): p.42-46, 136-8.

Liner notes for The Art of Wanda Landowska. RCA Victor-Veritas VM 104. 1967. LP.

RICHARD, J.A. The Pleyel Harpsichord. The English Harpsichord Magazine 2, no. 5 (1979): p.110-113.

RIFKIN, Joshua. The Dialectic of Dreams. Goldberg 50 (Feb. 2008): p.21.

RODRIGUEZ, Suzanne. Wild Heart: A Life: Natalie Clifford Barney and the Decadence of Literary Paris. New York: Harper Collins Publishers Inc., 2002.

ROLLAND, Romain. Musicians of To-day [Musiciens d'aujourd'hui. Paris: Librairie Hachette Et Cie, 1912], translated by Mary Blaiklock. New York: Henry Holt and Company, 1915. 
ROSS, Alex. Infernal Machines: How Recordings Changed Music. In Listen to This. New York: Farrar, Straus, and Giroux, 2010. ROSS, James. Music in the French Salon. In French Music since Berlioz, edited by Richard Langham Smith and Caroline Potter. Burlington, Vermont: Ashgate, 2006.

RUE VISCONTE. La Rue Mystérieuse. "Le Temple de I'Amitié." http://www.ruevisconti.com/LaRueMysterieuse/TempleAmitie.html (accessed Mar. 16, 2010).

RUTLEDGE, John B. Late 19 ${ }^{\text {th }}$-Century Viol Revivals. Early Music 19, no. 3 (Aug. 1991): p.409-418.

SACHS, Harvey. Virtuoso: The Life and Art of Wanda Landowska. New York: Thames and Hudson, 1982.

SADIE, Stanley. The Idea of Authenticity. In Companion to Baroque Music, edited by Julie Anne Sadie. Berkeley and Los Angeles: University of California Press, 1998, c1990.

SADLER, Graham. Vincent d'Indy and the Rameau Oeuvres complètes: A Case of Forgery? Early Music 21, no. 3 (Aug. 1993): p.415-421.

SALANNE, Martine Lapène. Les Variations Scarlatti de Wanda Landowska: Enquête sur une composition d'interprète. Paris: Séguier, 2010.

SCHMIDT, Carl. Entrancing Muse: A Documented Biography of Francis Poulenc. Lives in Music No. 3. Hillsdale, NY: Pendragon Press, 2001.

. The Music of Francis Poulenc: A Catalogue. Oxford: Clarendon Press, 1995.

SCHOTT, Howard. Wanda Landowska: A Centenary Appraisal. Early Music 7, no.4 (Oct. 1979): p.467-472.

SCHUBERT, Emery, and Dorottya Fabian, The Dimensions of Baroque Music Performance: A Semantic Differential Study. Psychology of Music 34 (2006): p.573-587. http://pom.sagepub.com/cgi/content/abstract/34/4/573 (accessed Feb 19, 2010).

SHELEMAY, Kay Kaufman. Toward an Ethnomusicology of the Early Music Movement: Thoughts on Bridging Disciplines and Musical Worlds. Ethnomusicology 45, No. 1 (Winter, 2001): p.1-29.

SHERMAN, Bernard. Inside Early Music. New York: Oxford University Press, 1997.

SIGNET. Wanda Inspiratrice des Auteours Saint-Loupiens: Nouvelles et Poèms. Cinquantieme Anniversaire de la Mort de Wanda Landowska: Wanda Landowska a Saint-Leu. Bulletin des Amis de la Bibliothèque municipale Albert Cohen (St Lue-95). October, 2009. http://www.signets.org/images_evenements/09-10-signets-special-wanda-allege.pdf (accessed Mar. 17, 2010).

SIGNET-MARTY, Daniel. Cinquantieme Anniversaire de la Mort de Wanda Landowska: Wanda Landowska a Saint-Leu. Bulletin des Amis de la Bibliothèque municipale Albert Cohen (St Lue-95), October 2009. http://www.signets.org/ images_evenements/09-10-signets-special-wanda.pdf (accessed Mar. 17, 2010).

SILVERMAN, Willa A. Female Anti-Semitism during the Dreyfus Affair: The Case of Gyp. In Gender and Fascism in Modern France, edited by Melanie Hawthorne and Richard J. Golsan, p.12-26. Contemporary French Culture and Society. Hanover and London: University Press of New England, 1997.

The Notorious Life of Gyp: Right-Wing Anarchist in Fin-de-Siècle France. New York: Oxford University Press, 1995.

. Fin-de-Siècle Amazons: Antidreyfusard Women and the Affair. In Intolérance et indignation: L'Affaire Dreyfus, edited by Jean-Max Guieu. Paris: Fischbacher, 2000.

SIMMS, Bryan Randolph. Alexandre Choron (1771-1834) as a Historian and Theorist of Music. Ph.D. dissertation, Yale University, 1971.

SMITH, Patricia Juliana. Wanda Landowska. An Encyclopedia of Gay, Lesbian, Bi-Sexual, Transgender, and Queer Culture. http://www.glbtq.com/arts/landowska_w.html (accessed Jan. 20, 2010).

SOUHAMI, Diana. Wild Girls: Paris, Sappho and Art: The Lives and Loves of Natalie Barney and Romaine Brooks. New York: St. Martin's Press, 2004.

STING. Allessandra Ferri and Sting: Prelude Bach Cello Suite no. 1. Music For Dancers. 2008. http://musicfordancers. wordpress.com/2008/04/22/alessandra-ferri-and-sting-prelude-bach-cello-suite-no1/ (accessed Mar. 21, 2010).

Songs from the Labyrinth. Deutsche Grammophon CD 1703139. 2006. Compact disc.

The Journey and the Labyrinth. Deutsche Grammophon. http://www2.deutschegrammophon.com/ special/?ID=sting-dowland (accessed Mar. 21, 2010).

. Twin Spirits: Sting performs Schumann. Opus Arte. 2009. DVD.

STRAVINSKY, Igor, and Robert Craft. Memories and Commentaries. London: Faber and Faber, 2002.

Songs: 1906-1920 [Pastorale]. Mineola, NY: Dover, 2005.

Pastorale: Chanson sans paroles pour une voix et quatre instruments à vent. Mainz: Schott, 1933.

TAITHE, Bertand. Citizenship and Wars: France in Turmoil 1870-1871. New York: Routledge, 2001. 
TARUSKIN, Richard, Daniel Leech-Wilkinson, Nicholas Temperley, and Robert Winter. The Limits of Authenticity. Early Music 12, no. 1 (Feb. 1984): p.3-25.

Alte Musik or Early Music. Paper presented at conference titled "Die Wiener Schule und die Alte Musik." Vienna, Austria, 8-10 0ct. 2009.

Early Music: Truly Old-Fashioned at Last? New York Times. August 6, 2006 [also in The Danger of Music and Other Anti-Utopian Essays. Berkeley, Los Angeles, and London: University of California Press, 2009].

The Pastness of the Present and the Presence of the Past. In Authenticity and Early Music: Some Issues and Questions, edited by Nicholas Kenyon, p.137-207. Oxford: Oxford University Press, 1988. Resisting the Ninth. Nineteenth-Century Music 12, no.3 (1988-89): p.241-256.

Stravinsky and the Russian Traditions: A Biography of the Works through Mavra. Berkeley and Los Angeles: University of California Press, 1996.

Text and Act: Essays on Music and Performance. Oxford: Oxford University Press, 1995.

TIMBRELL, Charles. French Pianism: A Historical Perspective. Portland, OR: Amadeus Press, 1999.

THOMSON, Andrew. Vincent d'Indy and His World. Oxford: Clarendon Press, 1996.

TOMMASINI, Anthony. Television Review: The Resolute Discoverer of the Harpsichord. The New York Times, July 10, 1999, B15. http://www.nytimes.com/1999/07/10/movies/television-review-the-resolute-rediscoverer-of-the-harpsichord. html?pagewanted=1 (Accessed Mar. 10, 2010).

TRUMBLE, Robert. Vincent d'Indy: His Greatness and Integrity. Caulfield North, Victoria: R. Trumble, 1994.

VALLAS, Léon. Vincent d'Indy. Paris: Albin Michel, 1950.

DE VRIES, Willem. Sonderstab Musik: Music Confiscations by the Einstazstab Reichsleiter Rosenberg under the Nazi Occupation of Western Europe. Amsterdam: Amsterdam University Press, 1996.

WALLS, Peter. History, Imagination, and the Performance of Music. Rochester, NY: Boydell Press, 2003.

WALSH, Stephen. Stravinsky: A Creative Spring: Russia and France, 1882-1934. New York: Alfred A. Knopf, 1999.

WATCHORN, Peter. Isolde Ahlgrimm: Vienna and the Early Music Revival. Burlington, VT: Ashgate, 2007.

WEBER, William. Concerts at Four Conservatories in the 1880s: A Comparative Analysis. In Musical Education in Europe (1770-1914): Compositional, Institutional, and Political Challenges Vol. 2, edited by Michael Fend and Michel Noiray, p.331-349. Musical Life in Europe 1600-1900: Circulation, Institutions, Representation. Berlin: Berliner Wissenschafts-Verlag, 2005.

WHITE, Michael. Period Music Grow Up. Period. New York Times, August 6, 2006, Music Section, http://www.nytimes. com/2006/08/06/arts/music/06whit.html?ref=arts (Accessed Mar. 21, 2010).

WILSON, Stephen. Ideology and Experience: Anti-Semitism in France at the Time of the Dreyfus Affair. Oxford and Portland, OR: Littman Library of Jewish Civilization, 2007.

WISTER, Frances, editor. Twenty-Five Years of the Philadelphia Orchestra: 1900-1925. Philadelphia: The Womens Committee for the Philadelphia Orchestra, 1925.

WORRINGER, Wilhelm. Abstraktion und Einfühlung; ein Beitrag zur Stilpsychologie München: R. Piper, 1908

ZALTSBERG, Ernst. The Turbulant Life and Legacy of Harpsichordist Wanda Landowska. Clavier 41, no. 8 (0ct. 2002): p.16-21

ZASLAW, Neal. Liner notes for Wolfgang Amadeus Mozart: Piano Concertos nos. 25 \&t 26, Malcolm Bilson, fortepiano, John Elliot Gardner, conductor, The English Baroque Soloists. Archiv 423119. 1988 (rec. 1986). LP.

ZOLA, Emile. The Dreyfus Affair: 'J'accuse' and Other Writings, edited by Alain Pagès and translated by Eleanor Levieux. New Haven \& London: Yale University Press, 1996.

ZUCKERMANN, Wolfgang. The Modern Harpsichord: Twentieth-Century Instruments and Their Makers. New York: October House Inc., 1969. 


\section{Notas}

1 Taruskin's complete series of articles on "authenticity" is published in TARUSKIN, 1995, p.51-197. Numerous scholars and performers contributed to the "authenticity" debate in the 1980s and early 1990s, and two significant symposiums were devoted to the topic: (1) "Musical Interpretation: The Influence of Historically Informed Performance" at Oberlin College in March 1987 - discussion published in KENYON, 1988; and (2) "The Early Music Debate: Ancients, Moderns, Postmoderns" at the University of California, Berkeley in June 1990 - discussion published in KERMAN et al. 1992, p.113-30. The journal Early Music devoted an issue to "authenticity" (TARUSKIN et al. 1984, p.3-25). Also see DREYFUS, 1983, p.297-322.

2 T. E. Hulme (1883-1917), borrowing from WORRINGER, 1908, applies the terms "vitalist" and "geometrical" to movements in art. "You have these two different kinds of art. You have first the art [vitalist] which is natural to you, Greek art and modern art since the Renaissance. In these arts the lines are soft and vital. You have other arts [geometrical] like Egyptian, Indian, and Byzantine, where everything tends to be angular, where curves tend to be hard and geometrical, where the representation of the human body, for example, is often entirely non-vital, and distorted to fit into stiff lines and cubical shapes of various kinds" (HULME, 1924, p.82). Translation of WORRINGER, 1908 is in FRASCINA and HARRISON, 1982, p.50-64. Taruskin cites FURTWÄNGLER, [1950] 2005 as a "vitalist" recording.

3 "[Where] would have [Fritz Reiner] got his very modern ideas about baroque period style[?] You can be sure that he never read his Dolmetsch. In the 1910s, when Dolmetsch's great guidebook came out, Reiner was in Dresden, hobnobbing with Nikisch, Muck, Mahler, and Strauss, vitalists to a man the latter pair leaving us, in their compositions and arrangements, ample testimony to their utterly sentimentalized, fairyland vision of the eighteenth century. It must have been from the music of his own time from which Reiner (as great musicians do in all periods) formed his ideas about the music of other times. I believe it was Stravinsky who taught Reiner - and the rest of us - about Bach the geometrist, as it may have been Landowska - whom he heard as early as 1907 - who taught Stravinsky" (1988, p.166-7). "Dolmetsch's great guide book" is DOLMETSCH, 1915. Taruskin refers above to REINER, [1949] 2005.

4 Bruce Haynes brings Landowska's obscurity to our attention: "it is paradoxical and somewhat poignant that Wanda Landowska and Arnold Dolmetsch, the two original cultivators of "stylistic nostalgia," are unknown to most of the younger musicians active in HIP at the beginning of the twenty-first century" (HAYNES, 2007, p.38). Galia and Michael Melzer express a commonly held view of Landowska's style. "Wanda Landowska, who had adopted early instruments, played them according to the $19^{\text {th }}$-century tradition." (MELZER, 1994, p.38) Marchwica notices that it is "strange" that a "famous performer who taught so many good harpsichordists, [did] not have direct successors in the field of performance aesthetic." (MARCHWICA, 1999, p.446). Concerning register changes, Philip recognizes Landowska's influence on later generations of harpsichordists (PHILIP, 2004, p.209). Watchorn discusses Landowska's and Pleyel's aim to "adapt" and "redesign" the old instrument (WATCHORN, 2007, p.8-9).

5 Nikolaus Harnoncourt (1929- ), Gustav Leonhardt (1928- ), and Frans BRÜGGEN (1934- ).

6 He uses this term to differentiate Harnoncourt, Leonhardt, and Brüggen from Landowska's generation. He also draws a correlation between the peak of the modern early music movement in the 1980 s and the success of the compact disc.

7 For more detail on Choron and his concerts, see ELLIS, 2005, p.9-20, 25-7; ELLIS, 2005a, p. 125-44; HASKELL, 1996, p.6-7; and SIMMS, 1971, p.132-57.

8 In preparation for Holy Week at Saint-Gervais in 1892, Bordes scheduled over one-hundred rehearsals while d'Indy conducted fifty more sessions - all part of an effort to become familiar with this new old-music (DOWD, 1969, p.18). For more detail on Bordes and the Chanteurs, see ELLIS, 2005, p.105-11. For contemporary biographical information on Bordes, see D'INDY, 1927, p.9-26.

9 In the late 1980s, Taruskin recognized the necessity of adapting early repertoire to insure acceptance. "Modern audiences have been discovering a Bach they can call their own - or, in other words, Bach has at last been adapted with unprecedented success to modern taste. Our authentistic performers, whatever they may say or think they are doing, have begun to accomplish for the twentieth century what Mendelssohn et al. had accomplished for the nineteenth century. They are reinterpreting Bach for their own time." (1988, p.197)

10 Diémier taught piano at the Paris Conservatoire (1887-1919); Jules Delsart taught cello at the Conservatoire (1884-1900). For more detail on the Société des Instruments Anciens, see ELLIS, 2005, p.92-6; FAUSER, 2005, p.31-6; and RUTLEDGE, 1991, p.411, 415-6. For details on Société's St. Petersburg concert, see TARUSKIN, 1996, p.367-8. For more on Diémier, see TIMBRELL, 1999, p.50-2.

11 The defrocking happened earlier in Germany and Austria, where publications debated "authenticity" from the 1960s onward, well before the 1980s (FABIAN, 2001; and FABIAN, 2004).

12 Walter Goehr (1903-1960) conducted the concerto (London, 1937); he was the first in three generations of prominent musicians, musicologists, and philosophers. (Alexander, composer, is his son and the music philosopher, Lydia Goehr, is his granddaughter). Walter Goehr moved to Britain as a refugee from Nazi Germany. He was a student of Schoenberg and eventually became conductor/musical director of the Berlin Radio, the Columbia Graphophone Company and the BBC Theater Orchestra. In London, he premiered Britten's Serenade, Tippett's A Child of our Time and Seiber's Ulysses. Goehr was also a Monteverdi enthusiast and edited Poppea and the Vespers of 1610.

13 For additional descriptors gathered from interviews with listeners of early-music performances, see SCHUBERT, 2006, p.580.

14 In a review of Roger Norrington's 1987 recording of Beethoven's Ninth Symphony, Taruskin challenged the use of historical reference ("historical verisimilitude") as a defense for the "authentic" sound of music. He found Norrington's interpretation compelling, but disagreed with his authentistic premise (TARUSKIN, 1995, p.237-8). Also see argument in TARUSKIN, 1988.

15 After Landowska's exile from Paris, her library was confiscated by the Einsatzstab Reichls/eiter Rosenberg (ERR) around 20 September, 1940. The ERR shipped fifty-four crates to Berlin and, from there, distributed them to rural areas. The vast majority of her property is either nonextant (destroyed by bombing?) or believed to be held by private owners. For the ERR's inventory of Landowska's collection and more detail on the confiscation, see DE VRIES, 1996, p.217-29. A description of Landowska's instruments is provided in EIGELDINGER, 2006, p.224-5.

16 See m. 41. Measure numbers drawn from Neue Mozart-Ausgabe 15, no. 8.

17 See mm. 59-69.

18 See mm. 58-9, 78-80.

19 This articulated style resembles Philip's description of Landowska's performance of fast movements. He concludes that Landowska, on the harpsichord, produces rhythmic drive via the manipulation of articulation, mostly utilizing staccato playing. For an analysis of Landowska's performance of J. S. Bach's "Italian Concerto," see PHILLIP, 2004, p.59-61. Marchwica's description of Landowska's playing is similar to Phillip's: "sharply rhythmical and agogical contrasts, a simple and precise articulation." (1999, p.448)

20 See mm. 95-9.

21 The Haydn Concerto was recorded in 1937 under Eugène Bigot and with a different orchestra (Paris). K537 and Op. 21 were eventually released together (RCA Label). For details, see LANDOWSKA, 1937; ELSTE, 2010, p.222, 224; and RESTOUT, 1965, p.418-9. 
22 Pleyel and Company unveiled their harpsichord at the 1889 World's Fair. For more on the harpsichord and the World's Fair, see FAUSER, 2005, p.25-7; and BATTAULT, 2006, p.194-201. For more information on Pleyel and Landowska, see K0TTICK, 2003, p.425-9; LATCHAM, 2006, p.95110; BATTAULT, 2006, p.202-4; and RICHARD, 1979, p.110-3.

23 "[Landowska's] metal monster wasn't really a harpsichord, but it wasn't quite a piano either."

24 For a worthy reassessment of the inauthentic qualities of Landowska's instrument, see LATCHAM, 2006, p.95-110. Landowska unveiled the "Landowska-Pleyel" model during the Breslau (Wroclaw) Bach Festival in 1912.

25 Taruskin borrows the term Klangmaterialismus from REDLICH, 1936.

26 See mm. 58-9. Measure numbers drawn from Joseph Haydn Werke 15, no. 2.

27 See m. 180.

28 For more details on the Parisian print, see Haydn, 1983, p.185. For more on music of "the other," see AUBERT, [2001] 2007.

29 However, the technological constraints of the recording process can affect the musical interpretation; tempos may be altered, repeats not taken, and the recording procedure, such as standing next to a cone, can influence individual musical production. For more on the challenges of the recording procedure, see PHILIP, 2004, p.24-32; PHILIP, 1998, p.75-9; ROSS, 2010, p.55-68; and DAY, 2000, p.1-57.

30 Landowska's life is chronicled by numerous scholars and harpsichord enthusiasts, see RESTOUT, 1965; RESTOUT, 1960, p.136-8; CASH, 1990; ZALTSBERG, 2002, p.16-21; PALMER, 1989, p.46-61, 118-36; MARCHWICA, 1999; EIGELDINGER, 2006; GAVOTY, 1957; MARTY, 2008; SIGNETMARTY, 2009; ATTIE, 1997; PEYSER, 1925; SACHS, 1982; SCHOTT, 1979; SIGNET, 2009; TOMMASINI, $1999 ;$ SALANNE 2010; and ELSTE, 2010. For research on Landowska's struggles to establish her career and reputation, especially in relationship to gender; see FAUSER, 2006.

31 Musique ancienne is the title of Landowska's book (co-authored with her husband Henryk Lew) on historical performance (LANDOWSKA, 1909). The English translation is Music of the Past (1924). Musique ancienne incorporates material from her sixteen-page booklet titled, Bach et ses interprètes: Sur l'interpretation des Oeuvres de Clavecin de J.S. Bach (1905). An English translation of Sur l'interpretation (On the Interpretation of the Harpsichord Works of J.S. Bach) is available in RESTOUT, 1965, p.165-236. For critique of Musique ancienne, see ALDRICH, 1971, p.461-8.

32 In addition to her composition studies with Urban (teacher of J. Paderewski, M. Karlowicz, and J. Hofman), Landowska studied piano with Moritz Moszkowski (CASH, 1990, p.24). At the Hochschule, she was also a classmate of Hofman (CASH, 1990, p.37). For a detail account of the museum's inventory and history, see DROYSEN-REBER, 1988. Landowska was Professor of Harpsichord at the Hochschule from 1913-1919.

33 For more detail on "miscellany" concerts, see PASLER, 2009, p.217-29, 629-42, fig. 24-5; and WEBER, 2005, p.337-40.

34 Referred to by the French as the 1870 War (19 July 1870-10 May 1871). The German victory brought an end to Napoleon III and the Second French Empire. The Third Republic took its place. For more detail, see TAITHE, 2001; and HOWARD, 2001.

35 According to Pasler, Neoclassicism is a metaphor for the recovery of France's national identity and the social integration of the elites into French society (2009, p.630).

36 Landowska taught at the Schola from 1900-1912. D'Indy lists Landowska as a "Principaux solistes des concerts de la Schola." (D'INDY, 1927, p.235)

37 See English translation of Emile Zola's "Letter to M. Félix Faure, President of the Republic ('J'accuse')" [1898] in Z0LA, 1996, p.43-52.

38 For more on the Dreyfus Affair, see LINDEMANN, 1991, p.57-128; FORTH, 2004; and BEGLEY, 2009.

39 Paul Marie Théodore Vincent d'Indy (1851-1931), composer, studied for three years with Diémer (of Société des instruments anciens) and later with Franck at the Paris Conservatoire in 1873. His popularity and favorable reputation is revealed in numerous contemporary accounts such as ROLLAND [1912] 1915, p.112-38; JULLIEN and FERRARI, 1915, c1906, p.465-6; DEMUTH, 1951; TRUMBLE, 1994; VALLAS, 1950; and HILL, 191 (contains detailed descriptions of his compositions). Félix-Alexandre Guilmant (1837-1911), organist and composer, succeeded Charles-Marie Widor as organ teacher in the Paris Conservatoire (1896-1911), where he taught Marcel Dupré and Nadia Boulanger. He edited and published lesser-known keyboard works by early composers, such as Titelouze, Grigny, Clérambault, and Couperin. For more on Guilmant, see DICKINSON, 1911, p.488; D'INDY, 1929, p.27-38; and Thomson's article in the New Grove.

40 D'Indy thought that Wagner's music had more in common with Gregorian chant than with the impure "Italo-judaïque" style, which he affiliated with the Conservatoire. D'Indy believed that "authenticity" in art can only be achieved after a purging. This would facilitate a natural connection with the past. For more detail on d'Indy's political views, see FULCHER, 1999, p.33; FULCHER, 2005, p.48-50; PASLER, 2008; and CARROLL, 1995, p.21.

41 In response to the Conservatoire's competitive nature, d'Indy asserted with anti-Semitic intimations that students at the Schola were pursuing higher goals and would never be satisfied gaining profit from their artistic aims. See FULCHER, 1999, p.33; and ROLLAND, 1912, p.273-8. For more on the French nobility and the concours, see FULCHER, 1999, p.30; and CHARLE, 1988, p.410. For more detail on the Schola's curriculum, see appendix of D'INDY, 1929. For more detail on the Conservatory's Société des Concerts, see HOLOMAN, 2004.

42 For more detail on d'Indy, the Schola and the French political landscape, see FULCHER, 1999, p.30-2; FLINT, 2006; THOMSON, 1996, p.116-39, 160-78; ELLIS, 2005, p.107-11; and CARHART, 2001, p.169-82 (includes late twentieth-century description of Schola's facilities). For a detailed contemporary account of the Schola's history, musical aims, and activities, see D'INDY, 1929 (includes listing of faculty, graduates, curriculum, and concerts given); ROLLAND, 1915, p.283-98; and DOWD, 1969, p.31-49.

43 From Schweitzer's letter to Landowska dated 30 May 1959. Landowska died three months after the date of this letter. Their relationship was clearly kindred. "It was in 1899 in Paris. I no longer know just how our first meeting took place. I believe you had learned that I was a pupil of Widor and that I had had some talks about Bach with him. He asked me to give a lecture, on the master and his works, for his students at the Conservatoire. You yourself were associated with the Schola Cantorum. There was accordingly between us the gulf that existed between the Conservatoire and the Schola Cantorum. We crossed it... I spoke to you of Bach and of the nature of his work: through you I came to know the French masters of the clavecin... We can both consider ourselves privileged because we have been able to complete the work we have undertaken. And we shall continue in a spiritual relation during the years we are still on earth, you in America, I in Africa." (MURRAY, 1994, p.74)

44 This title is borrowed from FAUSER, 2006.

45 Barney (1876-1972), born in Dayton, Ohio, was a playwright, poet, and novelist who lived in Paris for over 60 years. Her Salon de I'Amazone brought together world renowned artists and writers. She was openly lesbian and a polyamorist, and her lovers fell in to three categories: "liaisons," "demi-liaisons," and "adventures." Her infamous relationships with women were surrounded by intrigue, one of her love-stricken liaisons Dolly Wilde killed herself.

46 Le ton was performed by Génia of the Comédie-Français and Francis de Miomandre (RODRIGUEZ, 2002, p. 195).

47 See RUE VISCONTE for history, restoration, and photographs of the Temple de l'Amitié. 
48 The sketch became the foldout insert (inside front cover) in BARNEY, 1929. The Carte du Salon de l'Amazone records guests from 1910-1930. For a reproduction of the sketch and more detail on Barney's salon, see SOUHAMI, 2004, p.60-3, unpaginated illustration after p.50; a reproduction of the sketch also appears in RODRIGUEZ, 2002, unpaginated illustration after p.234.

49 Antheil's radical First String Quartet, which Barney had financially supported, was premiered at Barney's salon on 1 January 1926 (ANTHEIL, 1945, p.173).

50 Restout on Landowska's relationship with Schunicke: "When finally Wanda was able to return to France, she had lost her father, her husband, most of her belongings. But she had met Elsa, who forever after was to be her most beloved and devoted companion." (Restout, 1965, p.138)

51 I presume the competition between Boulanger and Landowska happened at the École normale de musique de Paris in the 1920s and 1930s.

52 For more detail on Barney's anti-Semitism, see BENSTOCK, 1986, p.412-5.

53 For more on Gyp's reception as anti-Dreyfusard, see FORTH, 2004, p.137-8; SILVERMAN, 1995; and SILVERMAN, 2000. Silverman draws on Stephen Wilson's assertions about anti-Semitism during the Dreyfus Affair (WILSON, 2007).

54 For photos of Gyp, see SILVERMAN, 1995, unpaginated illustrations after p.165.

55 Drawn from Gyp's testimony at a trial of accused nationalist conspirators in 1899. See $6 n$ in SILVERMAN, 1997, p.13.

56 Landowska also played the harpsichord part for El retablo in performances in Seville and New York City. For reproduction of program from 25 June 1925 (includes explanatory paragraph by Landowska), see DENNIS, 2007, unpaginated illustration after p.23. For more detail on the commissioning, compositional process, and performance of El retablo in Polignac's salon and other venues, see KAHAN, 2003, p.231, 236-7, 389; STRAVINSKY, 2002, p.80; PAHISSA, 1954, p.119-29; HESS, 2001, p.199-231 (a list of early performances is in appendix 7); HESS, 2005, p.138-49; PAHLEN, 1994, p.142-6; and ELSTE, 2010, p.94-7.

57 For bibliographical information on Landowska's recordings of modern music on the harpsichord, see ELSTE, 1995, p.100, 162.

58 The public premier of de Falla's Concerto for Harpsichord and Chamber Orchestra took place in Barcelona on 5 November 1926. For more detail on de Falla's concerto, see HESS, 2001, p.232-61; PAHLEN, 1994, p.147-55; PAHISSA, 1954, p.131-42; and HESS, 2005, p.59-65 (provides, in detail, the circumstances surrounding their falling out). The first public performance of Poulenc's concerto was on 3 May 1929. For detail on the Poulenc commission, see BR00KS, 1993, p.454-5; SCHMIDT, 1995, p.151-7; KECK, 1990, p.10; SCHMIDT, 2001, p.164-9; PALMER, 1989, p.127-9 (1928 photograph of Poulenc and Landowska); and ELSTE, 2010, p.142-3 (1950 photographs of Poulenc and Landowska). Landowska was a significant figure in Poulenc's personal and musical life. For Poulenc's expression of gratitude towards Landowska, see RESTOUT, 1960, p.137. For more detail of Landowska's profound influence on Poulenc and analysis of Concert Champêtre, see IVRY, 1996, p.65-8, ill. 59, 66-7.

59 For a list of Landowska's recordings and radio broadcasts, see RESTOUT, 1965, p.411-23; and ELSTE, 2010, p.212-30. Landowska performed in Russia at the estate of Count Leo Tolstoy $(1907,1909)$, and her United States debut was with Stokowski and the Philadelphia Orchestra on 16 November 1923 (WISTER, 1925, p.223). For more detail on her concerts at Tolstoy's residence, see note 69. Her performance of Brandenburg $\checkmark$ at Carnegie Hall on 12 October 1923 was with the New York Symphony Orchestra. Landowska moved to New York City on 7 December 1941 (the bombing of Pearl Harbor) and eventually to Lakeville, Connecticut in 1947, where she lived until her death. Her final recital (1954) took place at the Frick Museum, New York City.

60 "I was somewhat alarmed by the hocus pocusness of the atmosphere and the general spirit of 'Isn't this old music just lovely. And nobody can play it but Landowska!"'

61 For more on Landowska's aura in performance, see FAUSER, 2006; LISZNIEWSKI, 1927; and ATTIE, 1997.

62 "My further capitulation came on Sunday, when this same music was given a dress rehearsal, plus some solo playing by Landowska, and the Mozart sonata for two pianos, played by Landowska and Gerlin, her chief pupil. And really, - I have only once heard Mozart playing that even approached the precision, brilliance, and delicacy of hers, and the way she could turn and mold the phrases and simply take you straight to heaven in the slow movements... She is a much greater musician than I first thought her." Kirkpatrick studied briefly with Landowska in 1931 and joined the music faculty of Yale University in 1940. For more of Kirkpatrick's comments on Landowska, see KIRKPATRICK, 1985, p.68-9; Buckley's interview in ATTIE, 1997, Chap. 7; CASH, 1990, p.180-1; and WATCHORN, 2007, p. 13-16.

63 The conference was held at London's Royal Festival Hall on 14-16 May 1977. Brown chaired the event that included papers by David Fallows, Brown, Anthony Rooley, Robert Donington, Christopher Hogwood, Anthony Baines, lan Harwood, Andrew Parrott, Peter Holman, Clifford Bartlett, J. M. Thomson, Philip Shirtcliff, Jeremy Montagu, Richard Phillips, and Michael Bagenal. The paper presentations and musical events of the conference are described and published in BROWN (1978).

64 By the late 1980s, the early music movement had infiltrated the mainstream market with recordings of Bach cantatas, Mozart operas, and Beethoven symphonies. Early music projects were ambitious and nearly unprecedented for the recording industry, such as: the 90-LP Harnoncourt/Leonhardt complete set of Bach cantatas (1971-1989), Hogwood's complete set of Mozart symphonies ([1979-1982] 1997), and Norrington's complete cycle of Beethoven symphonies ([1989] 1990). For more on the rise of historical performance and compact disc sales, see MEYER, 2009, p.249; and BUT, 2004, p.194.

65 Galia and Michael Melzer confer with BILSON, 1980: "A performing artist who has learned his authentic instrument - its colors and manner of speech, has the power to present the music in a more convincing way." (MELZER, 1994, p.61) The premise had been around since the 1950s, well before 1960s "authenticity." Paul Hindemith advocated for it in a speech given in Hamburg in 1950: "If we want to perform his [Bach's] music according to his intentions we ought to restore the conditions of performance for that time." (HINDEMITH, 1952, p.19; quoted by BUT, 2004, p.191) Although Hans Ferdinand Redlich had reservations: "The belief that the employment of ancient instruments alone ensures a historically faithful reading of old compositions shows an exaggerated appraisal of the purely material side of old music" (REDLICH, 1952, p.196; quoted in TARUSKIN, 2009, 34n). Butt asserts that period instruments through their limitations facilitate alternative forms of expression and interpretation, "just as blind people often develop more acute hearing, the deaf a better sight." (BUT, 2004, p.194) Butt emphasizes the play between the eternal work and the fleetingness of its performance: "Much of the meaning that a contemporary audience may have found in this music lay in unpredictable places - the person of the performer, the difficulty of an instrument or the formal perfection of the music measured against the necessary imperfections of the performance medium." (BUTT, 2004, p.203)

66 Fabian (2003) investigates post-war era recordings and defines the early-music style with four different "interpretations": (1) tempo and dynamics, (2) ornamentation, (3) rhythm, and (4) articulation. Golomb's dissertation (2004) investigates trends in early-music and moderninstrument performances and recordings of J.S. Bach's Mass in B Minor.

67 For Taruskin's argument, see note 3 above.

68 For the reproduction of J. \& W. Chester's edition of Pastorale, see STRAVINSKY, 2005, p.22-4. For the composer's 1923 arrangement for wind instruments, see STRAVINSKY, 1933. 
69 In 1907, Leo Tolstoy attended a performance by Landowska at a reception honoring Russian quests at the Salle Pleyel in Paris. He was enamored with the performance and invited Landowska and her husband Henry Lew to his country residence in Yasnaya Polyana for the Christmas holidays. (This marked the beginning of a long relationship with Tolstoy, his wife, and their daughter Alexandra.) According to publicity archives, Landowska's Russian tour prescribed numerous performances (FAUSER, 2006, p.22n). For detail on Landowska's performances in Yasnaya Polyana, see CASH, 1990, p.61-9; LANDOWSKA, 1908, p.322-3; LANDOWSKA, 1908a, p.95; and ELSTE, 2010, p.43-58; and note 70 below.

70 Landowska's harpsichord was a spectacle, and the reviewers took notice. The remarks below are from the RUSSKAYA MUZÏKAL'NAYA GAZETA, 1907, col. 316-7. I am grateful to Daria Titova for her translation. "Wanda Landowska is a very interesting pianist. She fell in love with the classic harpsichordists and dedicated herself to the study of their music. Under the influence of the West (mainly in France and Germany), she has partly selected, as her specialty, to execute these old Renaissance works, revived nowadays on a harpsichord - an instrument adequate to deliver the spirit of the past. We are saying "partly" because of what is done by the chamber group Kazaderus, which performs only on period instruments (they have a very talented harpsichordist Mr. Delerba). Madame Landowska plays both the harpsichord and modern piano in her concerts. If she does this to compare the construction, richness, and color of the two diverse instruments, it is hardly fair, for the harpsichord is different from the piano - as if to compare Haydn's lovely, modest, intimate chamber ensemble with that of Wagner's or Strauss's orchestra. But this mixture of instruments affected the quality of Madame Landowska's performance in an unfavorable way. For a modern listener, the difference in sound between these two instruments is intolerable, and in this case, the listener prefers a grand piano with great pleasure, rather than the harpsichord. The truth is that the harpsichord in our time is of novelty interest. Perhaps the whole program with only harpsichord gives quite an original art pleasure and rebuilds the entire epoch of piano style, but Madame Landowska's performance only lead to a certain point. We would rather hear this undoubtedly talented pianist perform on a modern piano and not on the harpsichord, which she tries to show."

"Madame Landowska's performance on the piano was filled with surprising tenderness, softness, and clarity. She has an ability to demarcate the polyphonic voices of in the harpsichord writing, which are inherent in character of this style. But with Madame Landowska on the harpsichord, one cannot involuntarily forget the influence (advancement) of piano technique. Her execution loses its tenderness and clarity with the monotonous and noisy pedaling. Instead, you sometimes hear noise, a mixture of original harpsichord registers, a rigid impact, and so on. The explanation of this could be the youth and inexperience of Madame Landowska. (By the way, she was born in 1881 in Warsaw, where she studied in the conservatory in a class of Prof. Mihalovsky and then in classes of Urban and Moshkovsky in Vienna [Berlin]. During the last years, she gave many concerts with great success in France, Germany, and England.) Having paid attention to the differences between old and modern instruments, she devotes herself exclusively to the cultivation of the harpsichord's style. This style is most likely to have a revival on the harpsichord, for the construction of the instrument quite differs from the piano, having more commonalities probably with an organ. The harpsichord, due to a vast number of pedals, has its own colors, but the abrupt jingling sounds absolutely differ from the force, smoothness, and shade sonorities of the piano, for which this rich literature Madame Landowska interprets in her concerts was not created. Her first concert on February 27, in Tenishev Hall was a great success and dedicated to the great Sebastian and his contemporaries. Not to speak only about Bach, those were pretty artful composers, who anticipated creative secrets well before the greatest artists of the nineteenth century. Take a listen to the "Gigue" from Bach's English Suite or the F-Minor Sonata by D. Scarlatti, and you most likely will agree that the first one could have been written by the creator of the Die Meistersinger, and the second by the creator of the Pastoral. By the way, Madame Landowska plays an instrument made by Pleyel, which is modeled after one owned by Bach, now held in Berlin's museum." For more details on her recitals, see TARUSKIN, 1996, p.368.

71 Facsimile of the Branle is found in FRANCISQUE, 1973, p.20v. Landowska might have performed from the edition issued by the Sociéte International de Musique (FRANCISQUE, 1906, p.52-4).

72 For more detail on Landowska-Stravinsky theory, see TARUSKIN, 1996, p.364-8; and WALSH, 1999, p.110.

73 Cash suggests this simple work was intended for Tolstoy's daughter, Princess Alexandra. For detail and transcription of Berceuse, see CASH, 1990, p.61-8.

74 Landowska recorded Bourree d'Auvergne in 1923, 1928, and 1951. This unpublished composition has not been dated, although it is similar to Berceuse. For detail on recordings of Bourree d'Auvergne, see RESTOUT, 1965, p.418.

75 The Works of Frederic Chopin and their Proper Interpretation ( 0 wykonywaniu dziel Szopina) was published in 1879 in Warsaw. The book was widely circulated, with translations in English (1913), French (1880, 1883, and 1906), Russian (1897), Dutch (1931), and Spanish (Mexico, 1949). For more bibliographical detail on The Works, see MICHALOWSKI, 1991, p.97. Kleczyński's observations of Chopin's performance style are based on traits exhibited by those "most nearly connected with Chopin by ties of friendship and talent." (KLECZYŃSKI, [1879] 1913, p.6) Landowska's article on Chopin interpretation shares Kleczyński's sentiments (LANDOWSKA, [1910] 1926, p.407-8). I am grateful to Joshua Rifkin for bringing my attention to the emigration of Varsovian composers to Paris.

76 Apparently Kleczyński said this with tears in his eyes (CASH, 1990, p.22). Landowska's mother felt Kleczyński's admiration for Landowska interfered with her daughter's education and eventually sent Landowska to a "more demanding" teacher, Alexander Michalowski (RESTOUT, 1965, p.6).

77 Landowska pursued a connection between Chopin and the music of the French Baroque keyboardists, but she was never able to produce evidence that Chopin knew French harpsichord music. She did, however, connect Chopin to eighteenth-century keyboardists on structural and hermeneutical grounds. "Here they are [connected] in their harmonic nature, with their ramifications and consequences; in their rhythmical complexity; in the phrasing of the melody; in the ornamentation; last but not least, they are evident in the esthetics of both composers." (RESTOUT, 1965, p.274-5) Also see LANDOWSKA [1910] 1926; and LANDOWSKA, 1931.

78 According to Philip, the infatuation with a metronomic pulse emerged after the Second World War (PHILIP, [1992] 2004, part I; and HAYNES, 2007, p.60). The concept of beat hierarchy is supported by Johann Quantz's eighteenth-century book on flute performance, whose meticulously annotated examples carry the weight of Holy Scripture for today's early music movement (QUANTZ, [1752] 2001, p.162-78).

79 Vogt, at the Paris conservatory from the 1820s, revised the phrasing in Girolamo Crescentini's vocalises (Vogt's pedagogical pieces were published in the 1860s). In contradiction to Crescentini's more cellular phrasing, adorned with messa de voce, Vogt advocates for a "straighter" long-line approach. For detail, see BURGESS, 2003, p.41-3; HARNONCOURT, 1988, p.25; and HAYNES, 2007, p.184-6.

80 This notational discrepancy could also reflect variations in different instruments - the piano verses the oboe.

81 Robin Hartwell also put forth the title "Post Authentic Performance Practice Movement." (HARTWELL, 1993, p.34)

82 Combattimento is led by violinist Jan Willem de Vriend. The modern-instrument early-music ensemble has produced recordings of Handel and Biber. In 2002, they performed Rameau's Platée at the Utrecht Early Music Festival. For philosophy on their use of modern instruments, see BACH-CANTATAS.COM. Emmanuel Music was founded by Craig Smith (1947-2007). For more detail, see EMMANUEL. 
83 Butt encapsulates a new view of historical performance: "Perhaps the ultimate value of studying all aspects of historical musical performance do not rest in telling us how a piece should or should not sound, but rather in how performance, as the medium of sounding music, conditions our idea of the way music relates both to the world in which it first sounded and to the world in which it sounds again. In other words, we are led to a broader conception of the way in which we use music from the past." (BUTT, 2006, p.15)

84 For more detail on recording, see STING, The Journey and the Labyrinth. Similar to the early music movement in the 1980s, Sting branched into Romantic repertoire. For more detail, see his theatrical production of Robert and Clara Schumann's letters (Sting, 2009).

85 A study published by Early Music America in 2005 supports Knighton's observation. It shows that audiences no longer distinguish a difference between early music and mainstream classical music (COLDWELL, 2005, p.2; and COLDWELL, 2008, p.25).

86 In 1989, Kelly speculated that "the field [of early music seems] to comprise three related elements: a body of music, those who perform it, and the way(s) in which the performers approach the music." $(1989$, p.2) Kelly admitted that the early music movement's borders were blurring. In 2001, Shelemay's abstract definition confirmed his suspicion. "From an ethnographic perspective, the early music movement can be seen less as a bounded stream of musical discourse than a multi-faceted world of musical and cultural experience. In terms of conventional parameters of time and space, one finds a virtually unlimited array of musics and musical practices from a full range of accessible historical styles primarily emerging from Europe and America, but infused both in the past and present with many cross currents." (SHELEMAY, 2001, p.10-1)

David Kjar, natural trumpet player and scholar, is the artistic co-director of the Boston-based ensemble Cambridge Concentus, which toured to Japan with Joshua Rifkin as director. As a natural trumpeter, David has performed and recorded with early music ensembles throughout Europe and North and South America while working with early music specialists such as Luis Otavio Santos, Joshua Rifkin, Sigiswald Kuijken, Rene Jacobs, Reinhard Goebel, and Richard Egarr. David is the natural trumpet professor in Juiz de Fora at Festival Pro-Musica and has taught and presented at the Semana Musica Antiga held at the Universidade Federal de Minas Gerais in Belo Horizonte. He holds a Bachelors Degree from the University of Northern lowa and Masters in Historical Performance from the Royal Conservatory of the Hague. David is currently pursuing a Ph. D. in Musicology at Boston University. His research focuses on eighteenth-century performance practice and notions of performance in the twentieth century, with special attention given to Wanda Landowska and her influence on the performance style of the early music movement. 